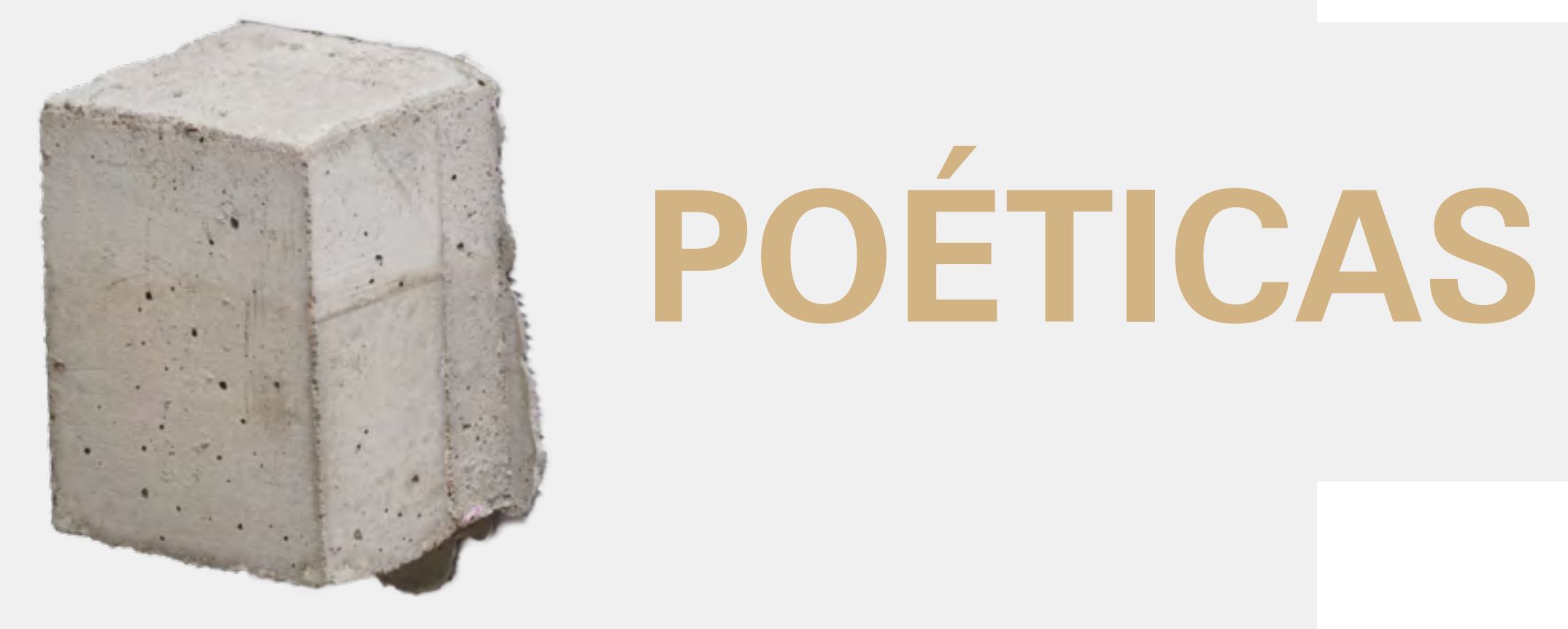




\section{NADA EM VÃO}

\section{Lucas Simões}

LUCAS SIMÕES, 1980

Vive e trabalha em São Paulo, Brasil.

Graduado em Arquitetura pela PUC-Campinas, 2003

Lucas Simões (1980, Catanduva, Brasil) realizou exposições individuais no Instituto Figueiredo Ferraz (Ribeirão Preto, Brasil), no Museu de Arte Moderna Aloísio Magalhães (Recife, Brasil), na Caixa Cultural (São Paulo e Rio de Janeiro, Brasil) e no Pivô Arte e Pesquisa (São Paulo, Brasil). Também participou de mostras na $10^{\mathrm{a}}$ Bienal do Mercosul (Porto Alegre, Brasil), Zacheta National Gallery (Varsóvia, Polônia), Astrup Fearnkey Musset (Oslo, Noruega), Itocho Ayoama Art Square (Tóquio, Japão) e no Museu Brasileiro da Escultura (São Paulo, Brasil). Suas obras fazem parte das coleç̃os públicas It Paula (São Paulo, Brasil), Museu de Arte do Rio de Janeiro (Rio de Janeiro, Brasil) e Museu de Arte Contemporânea da Universidade de São Paulo (São Paulo, Brasil).
A exploração da matéria como forma de expressão na obra de Lucas Simões não é, como a primeira vista pode parecer, um fetiche pela materialidade, mas, ao contrário, uma pesquisa que pretende preencher de significado o suporte do objeto artístico. Sua formação como arquiteto, onde técnica e poética estão profundamente entrelaçadas, dá uma das possíveis chaves de entendimento de sua produção.

Pintura, cartografia, livros, fotografia, concreto, aço, papel.. já foram objetos de sua investigação. Através de uma experimentação cotidiana com a matéria e o saber-fazer, o artista encontra os meios necessários de expressão, como nas esculturas e instalações mais recentes em concreto, que refletem sua pesquisa sobre arquitetura brutalista e ofracasso do seu sentido utópico.

\section{lucassimoes.com.br}




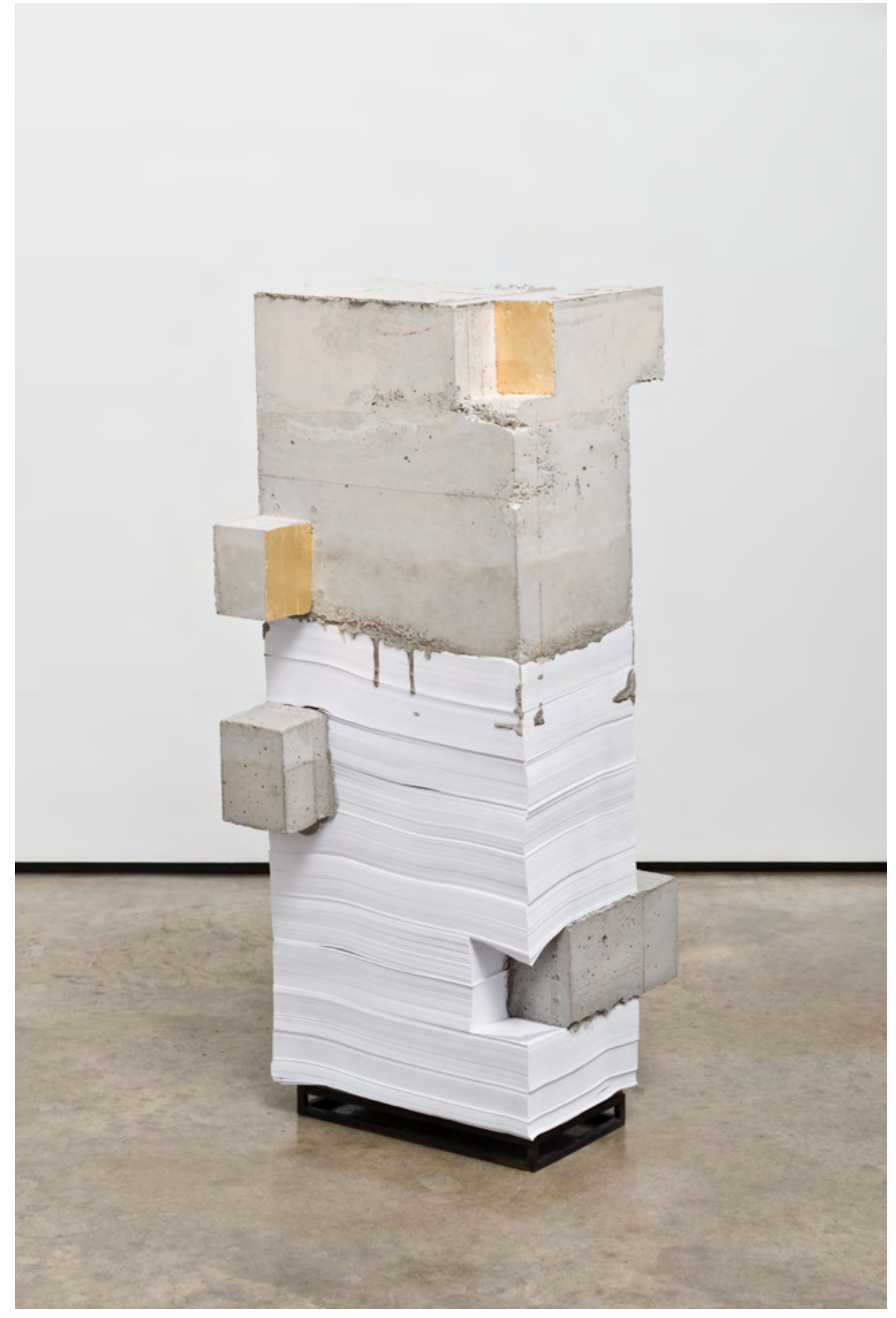




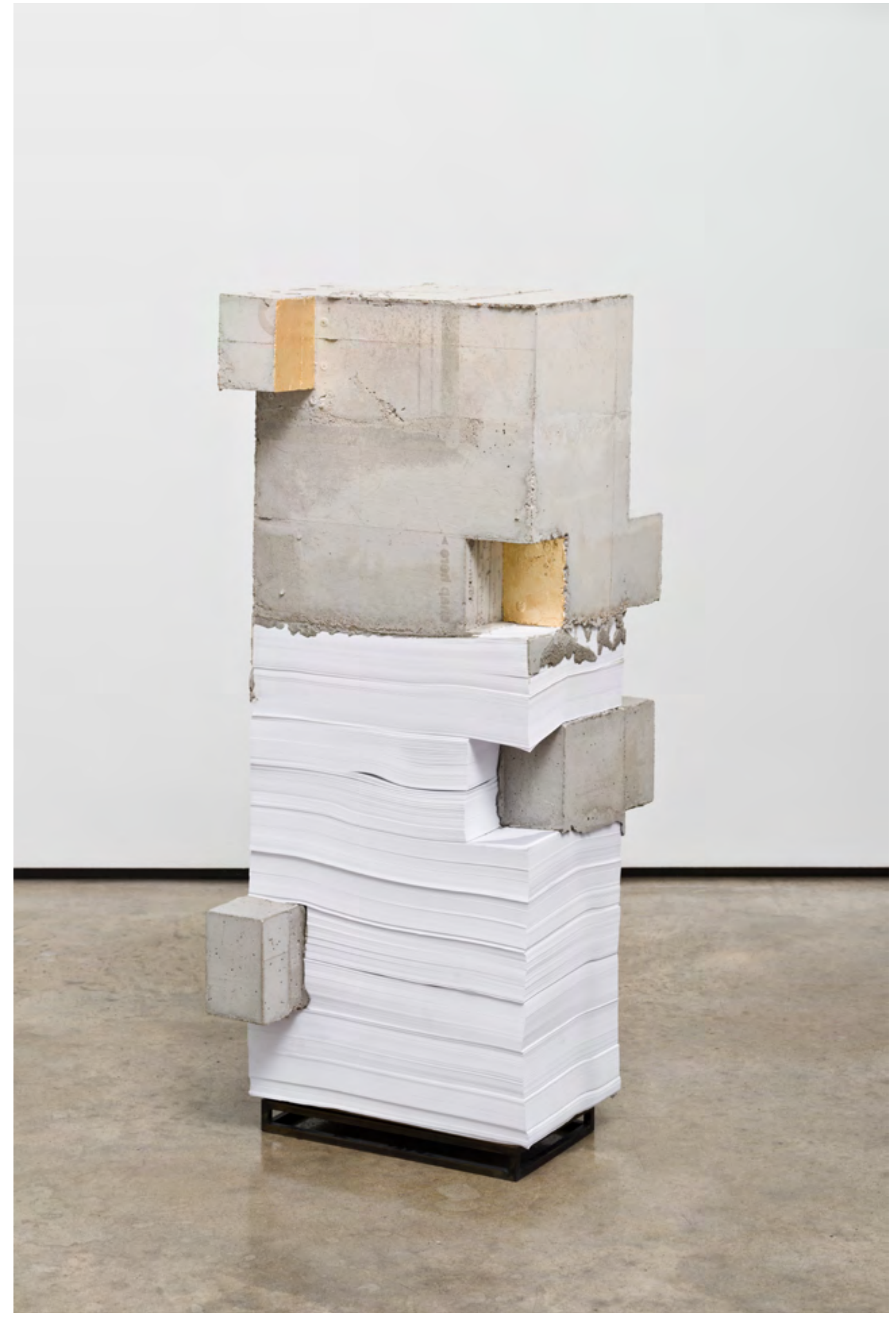




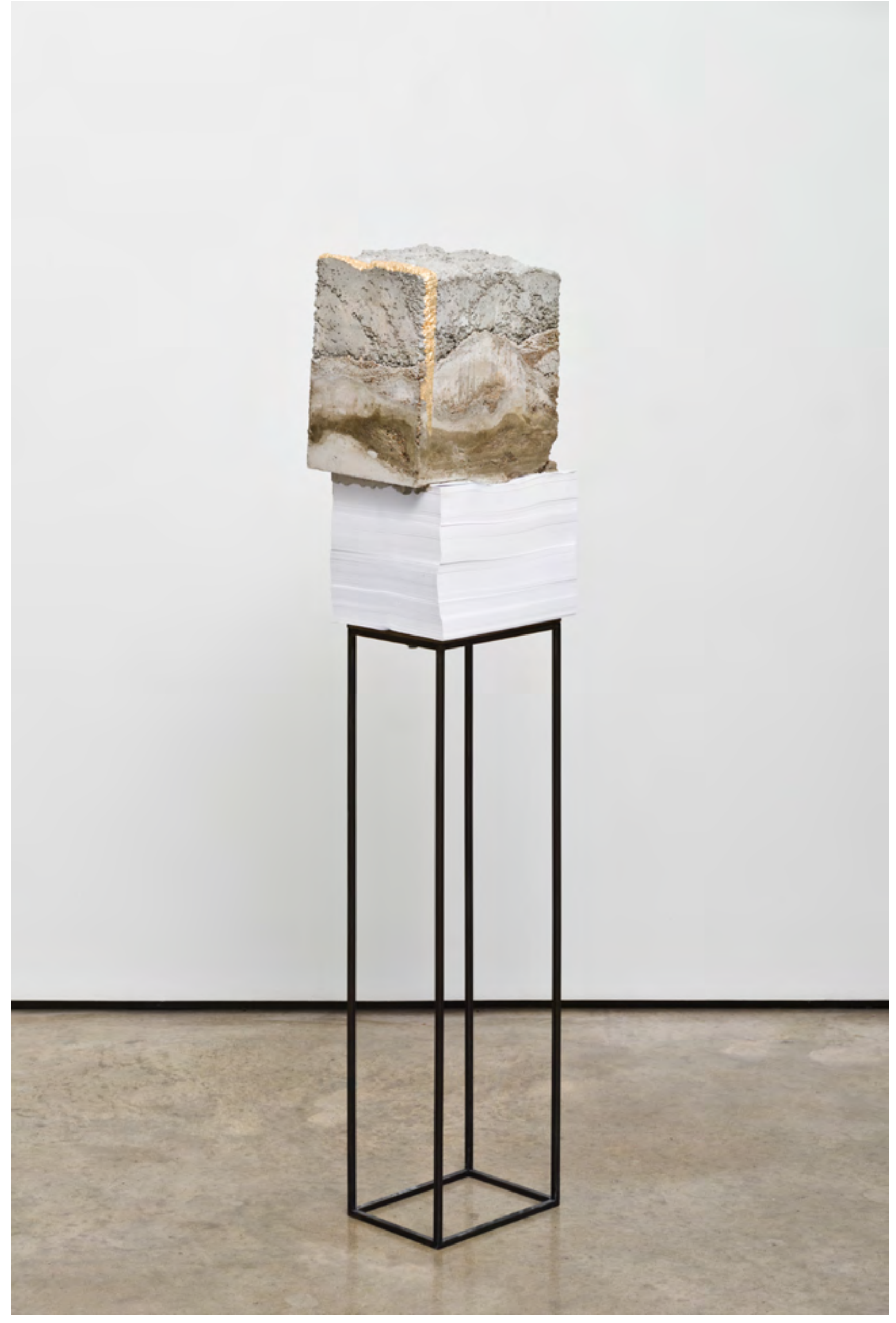



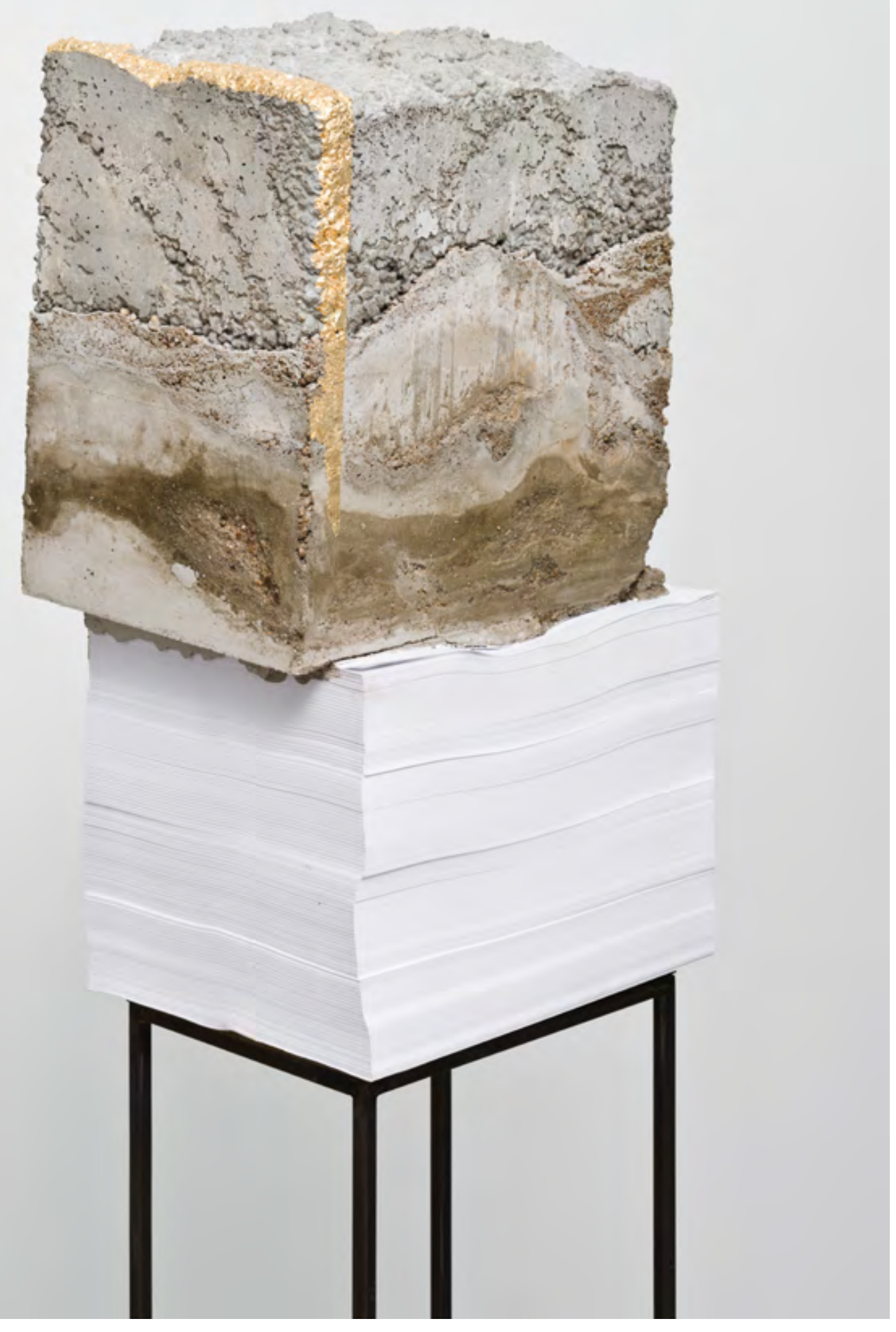


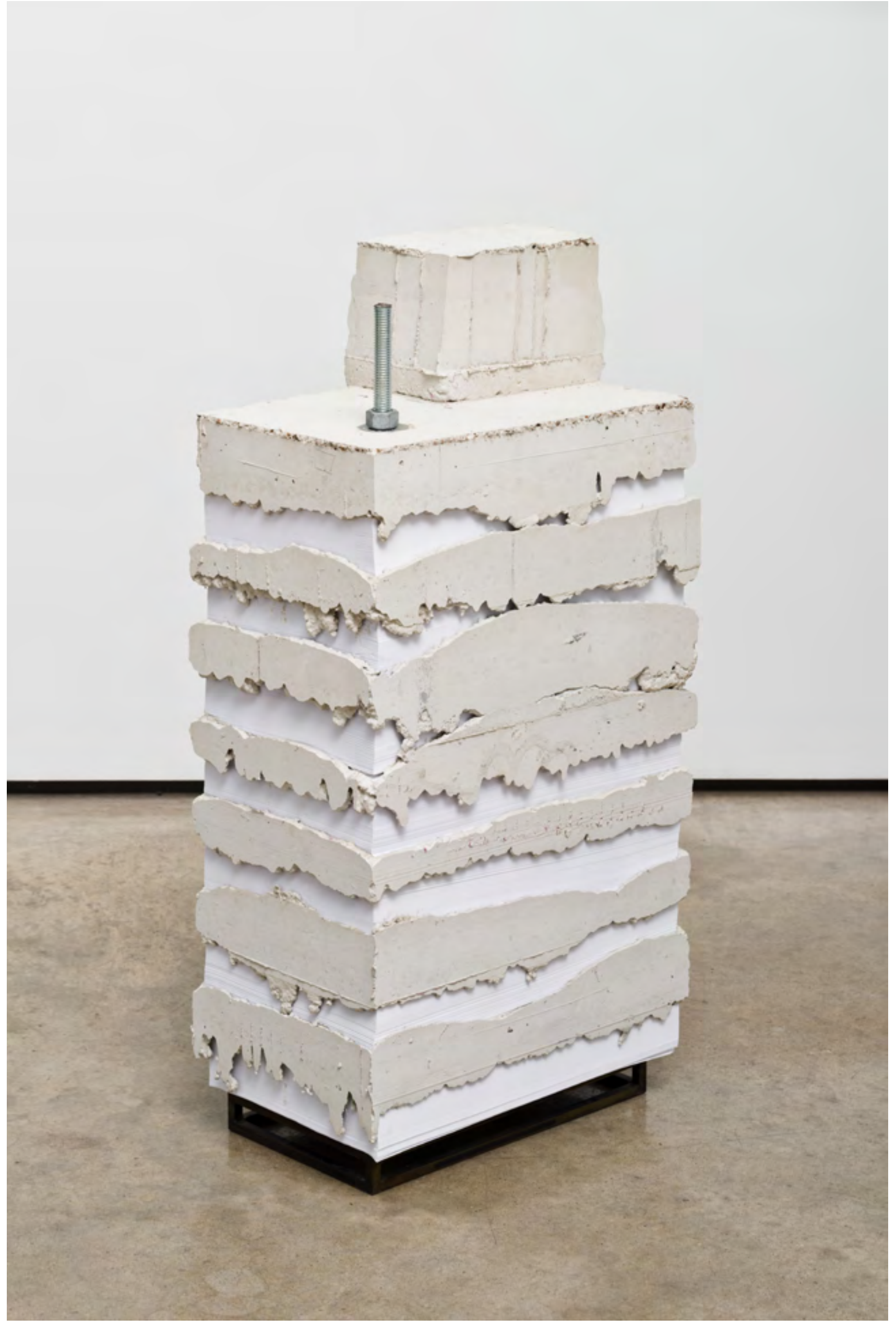




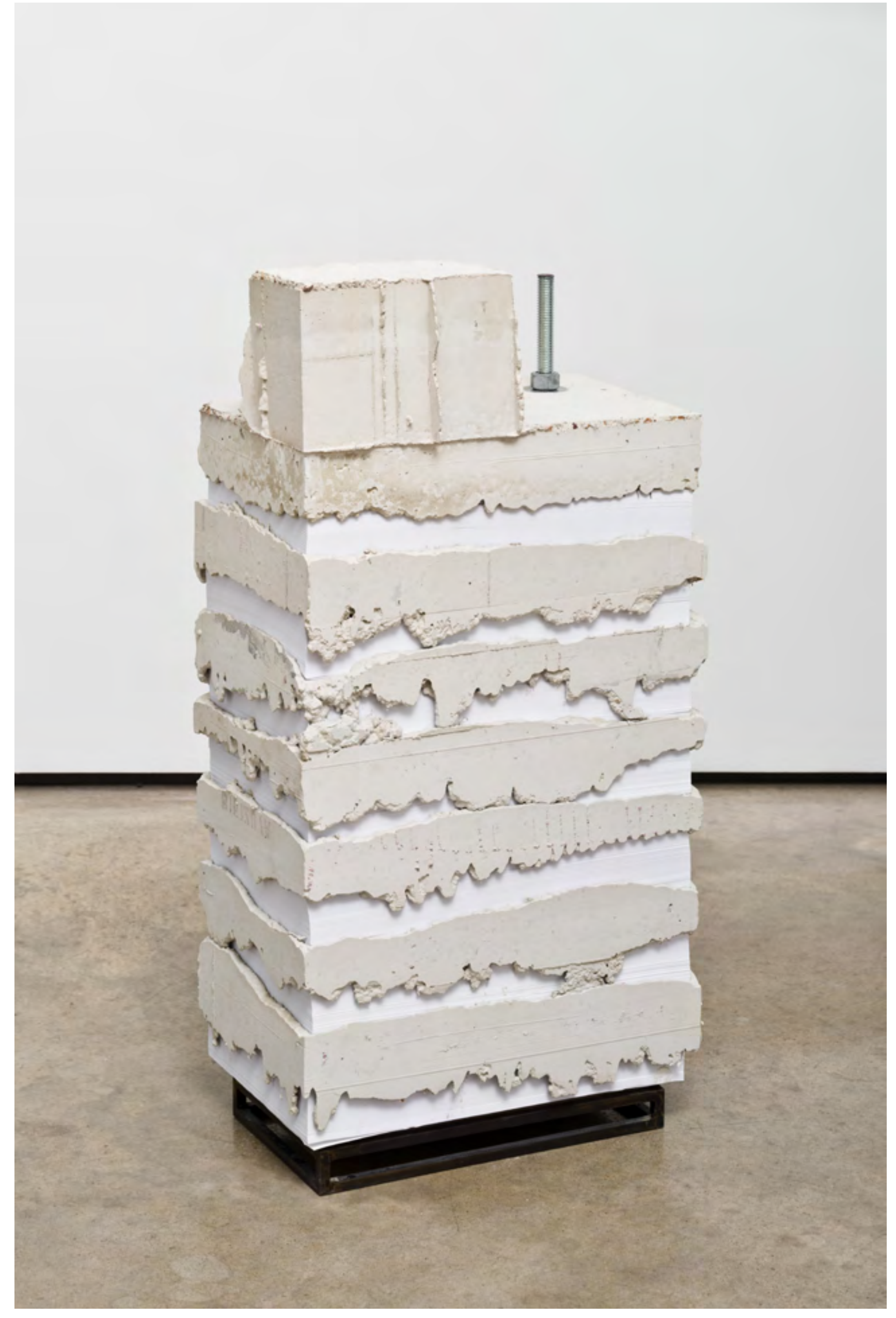




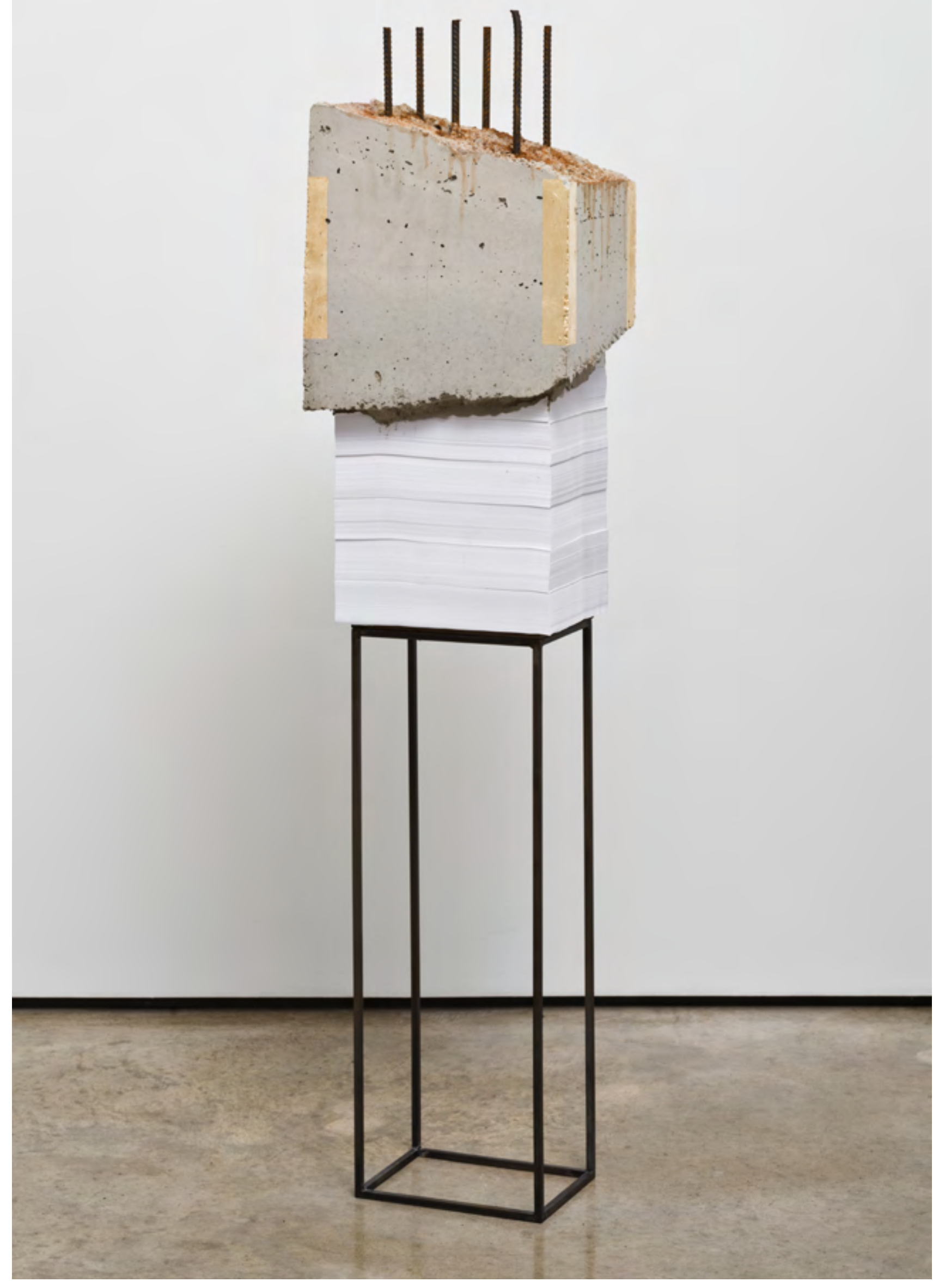




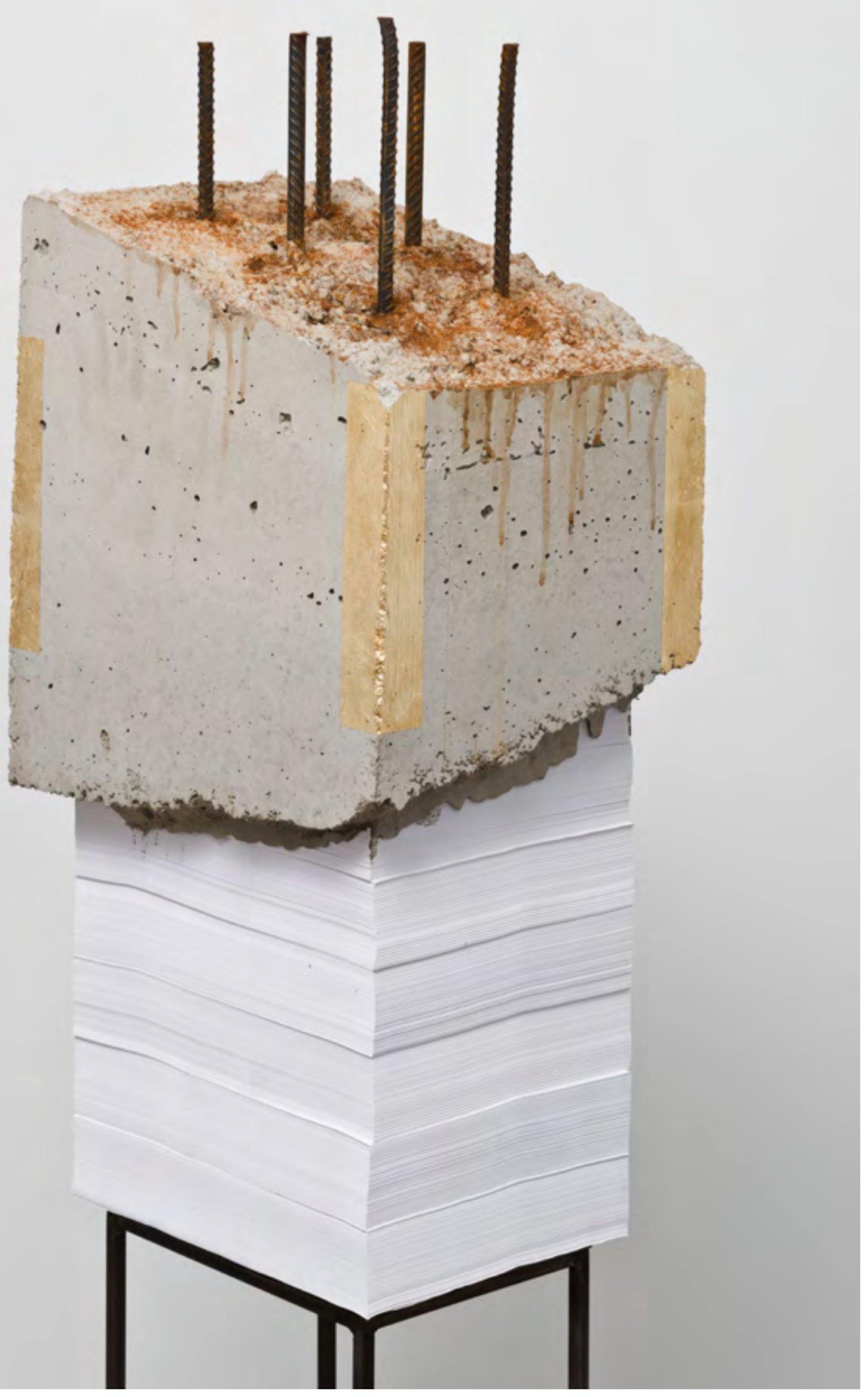




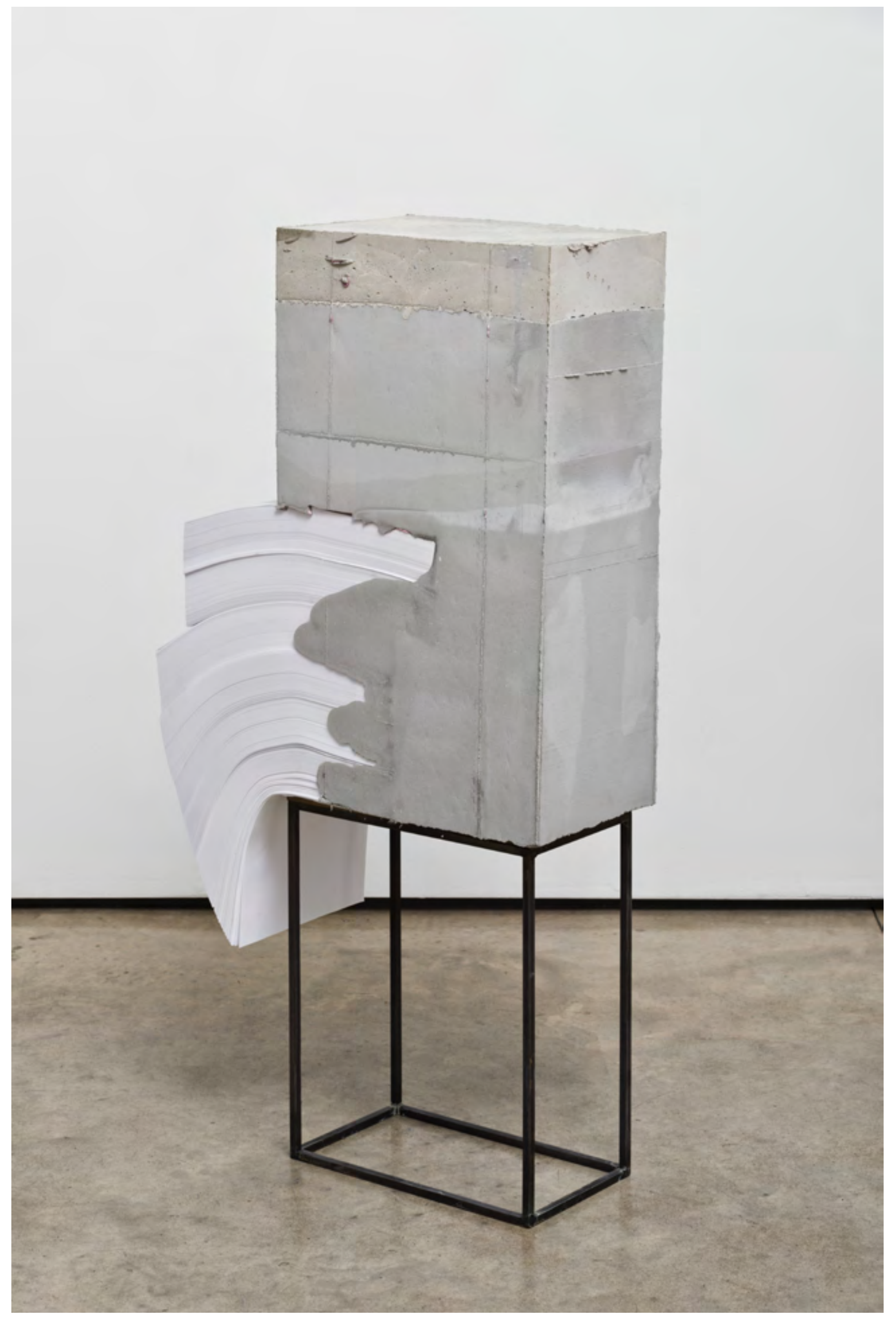




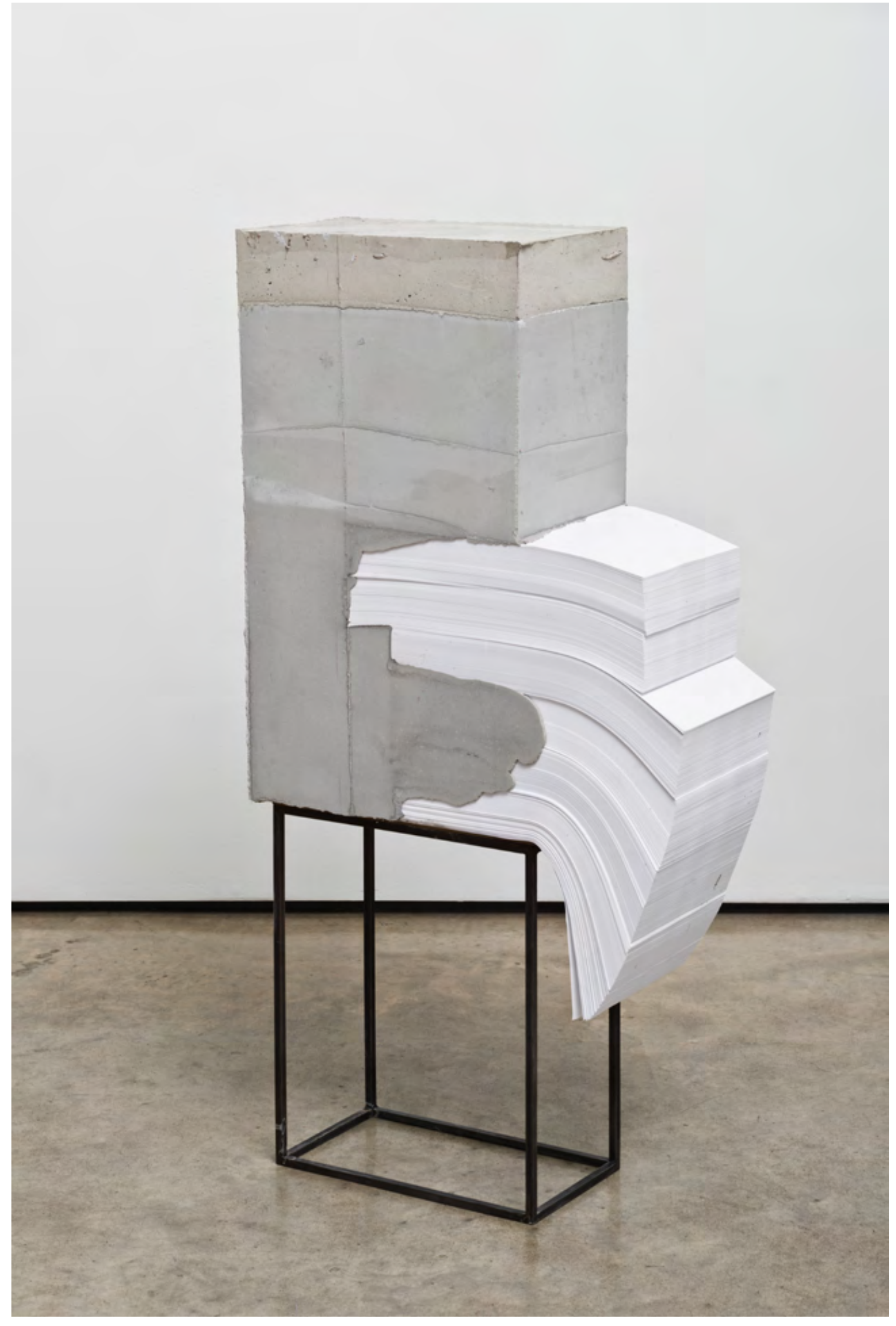




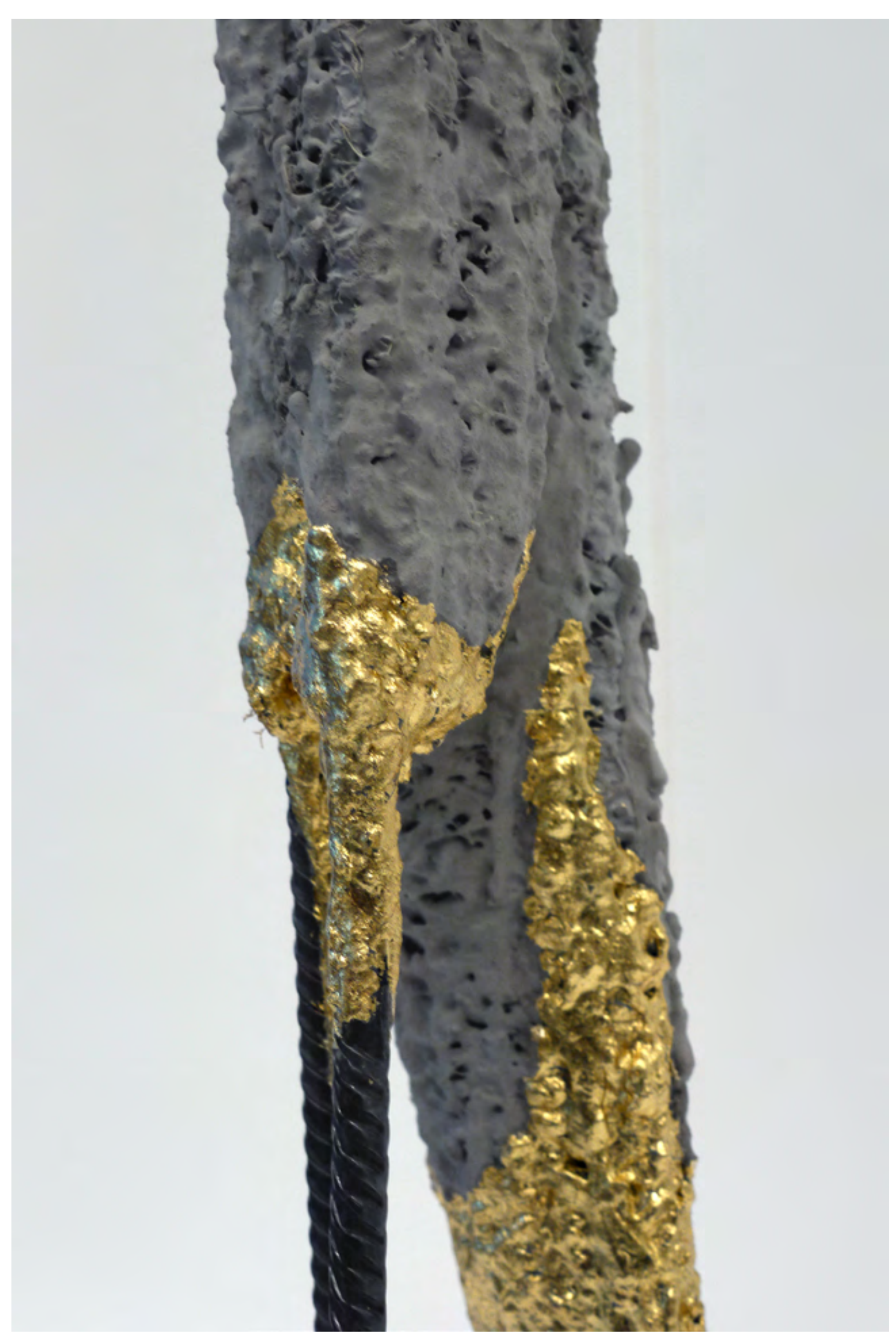




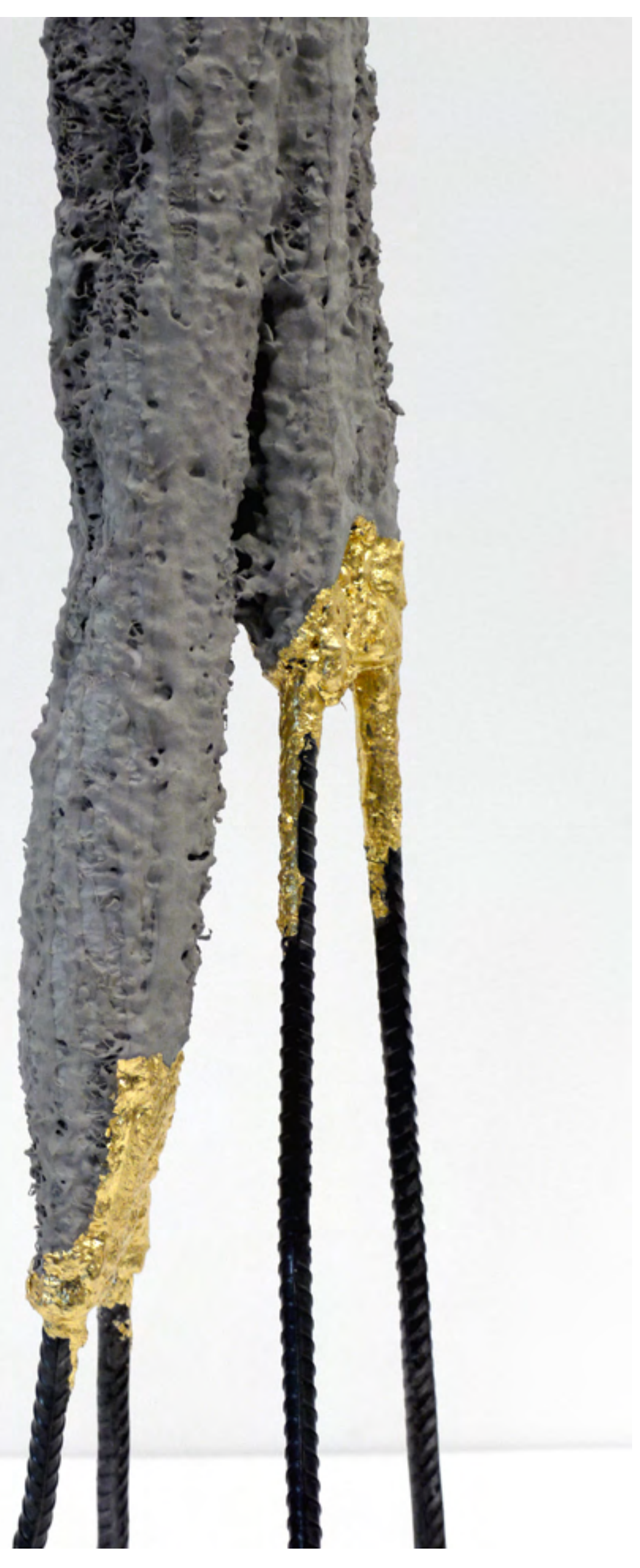




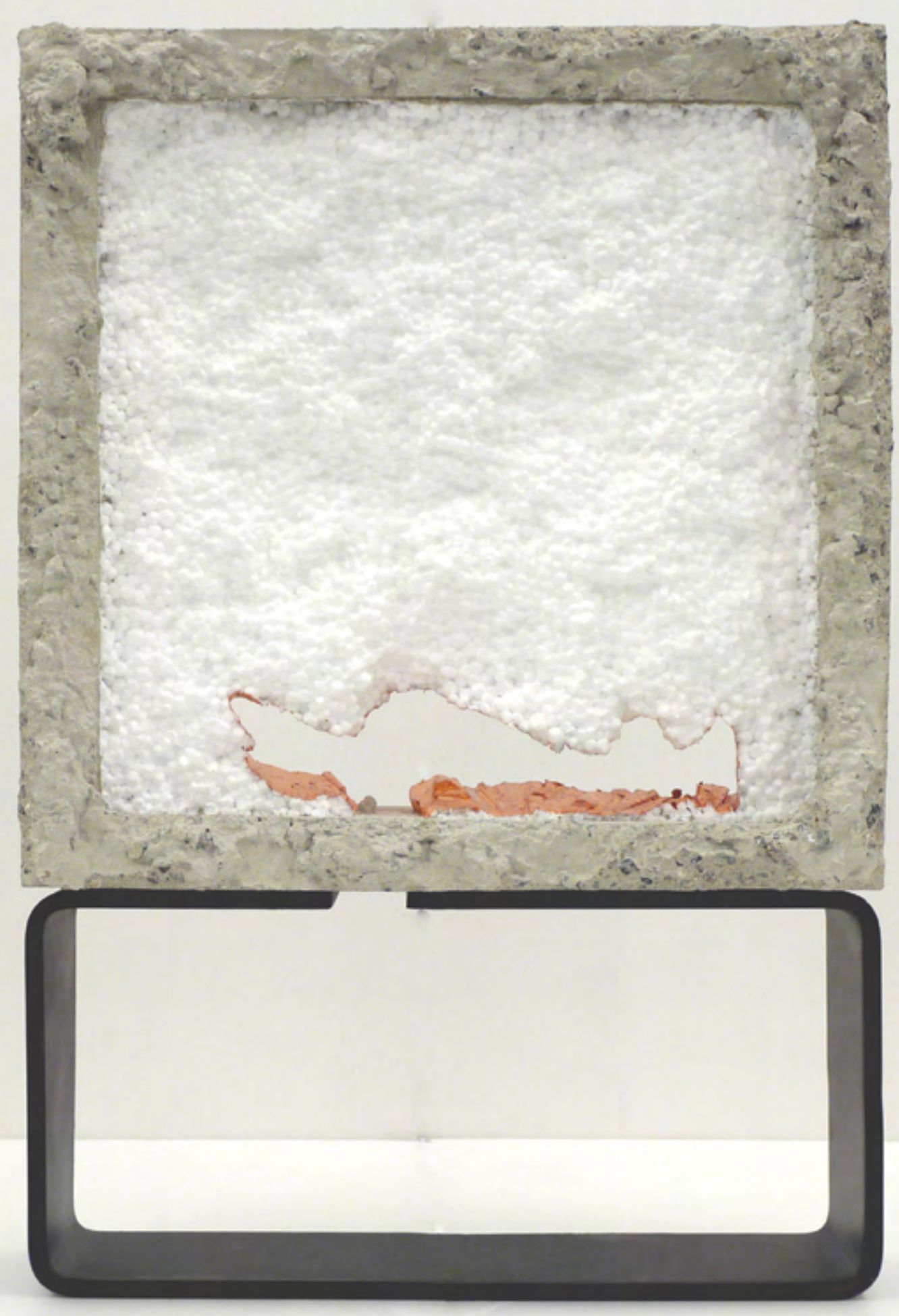




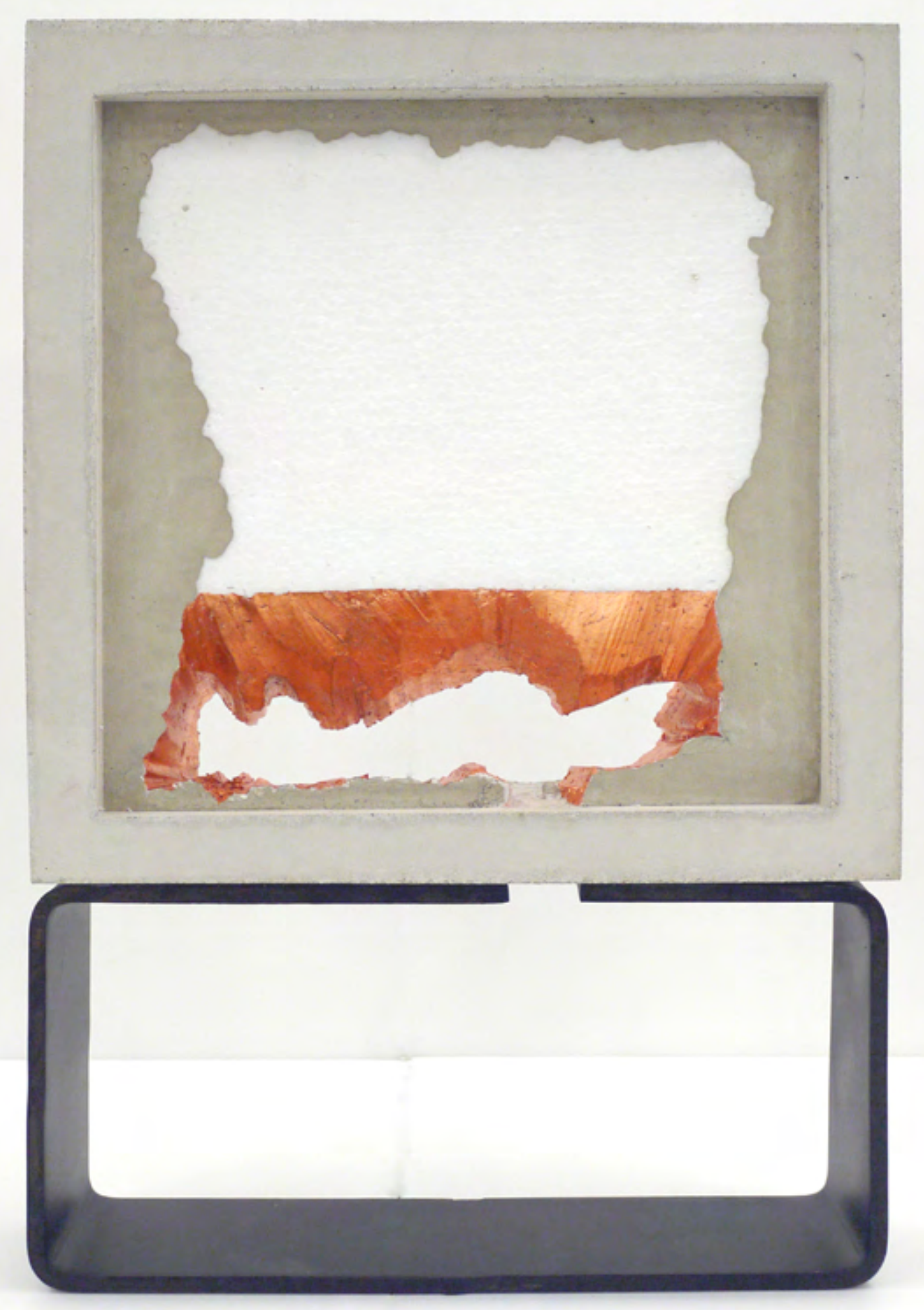



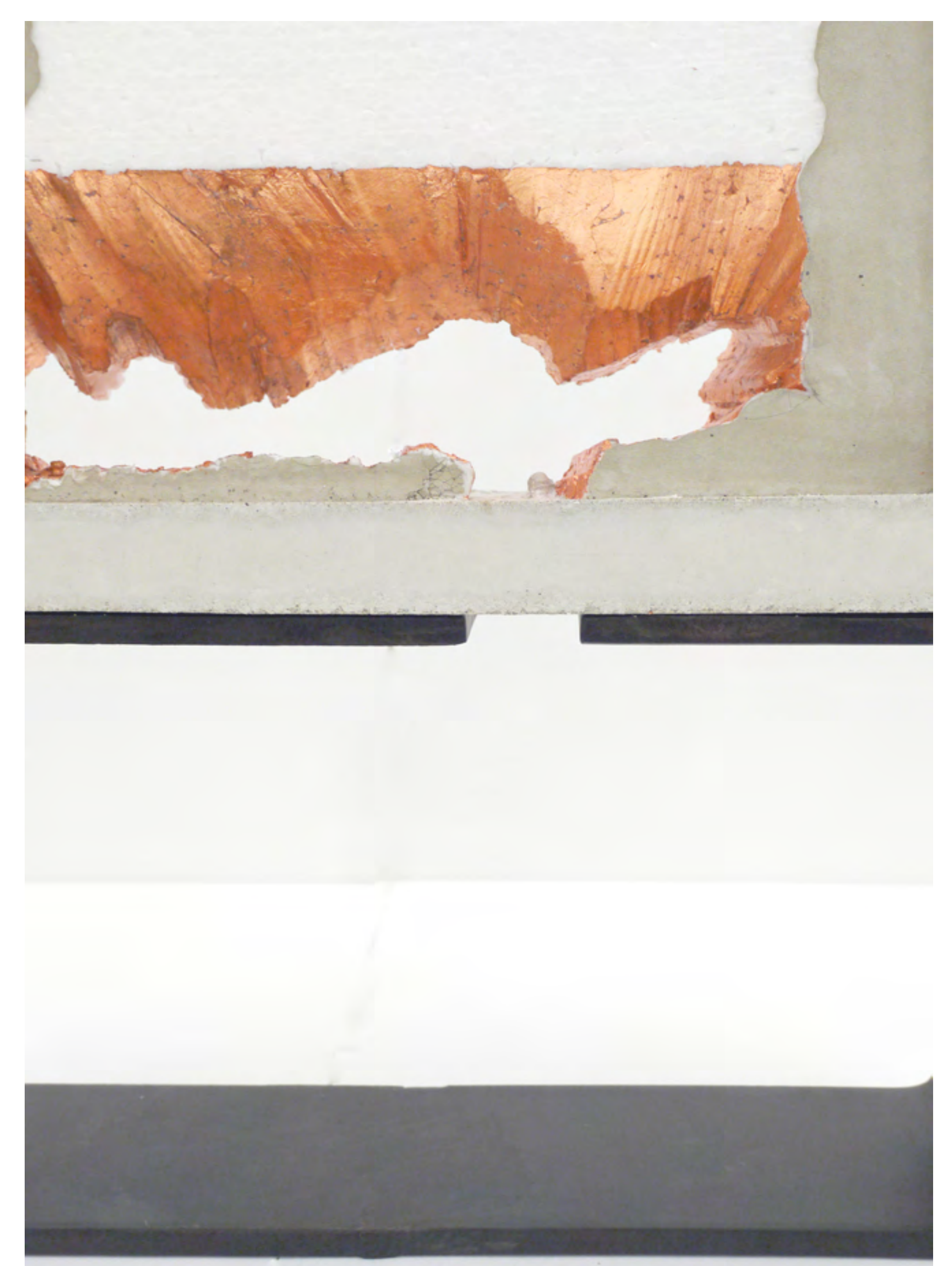


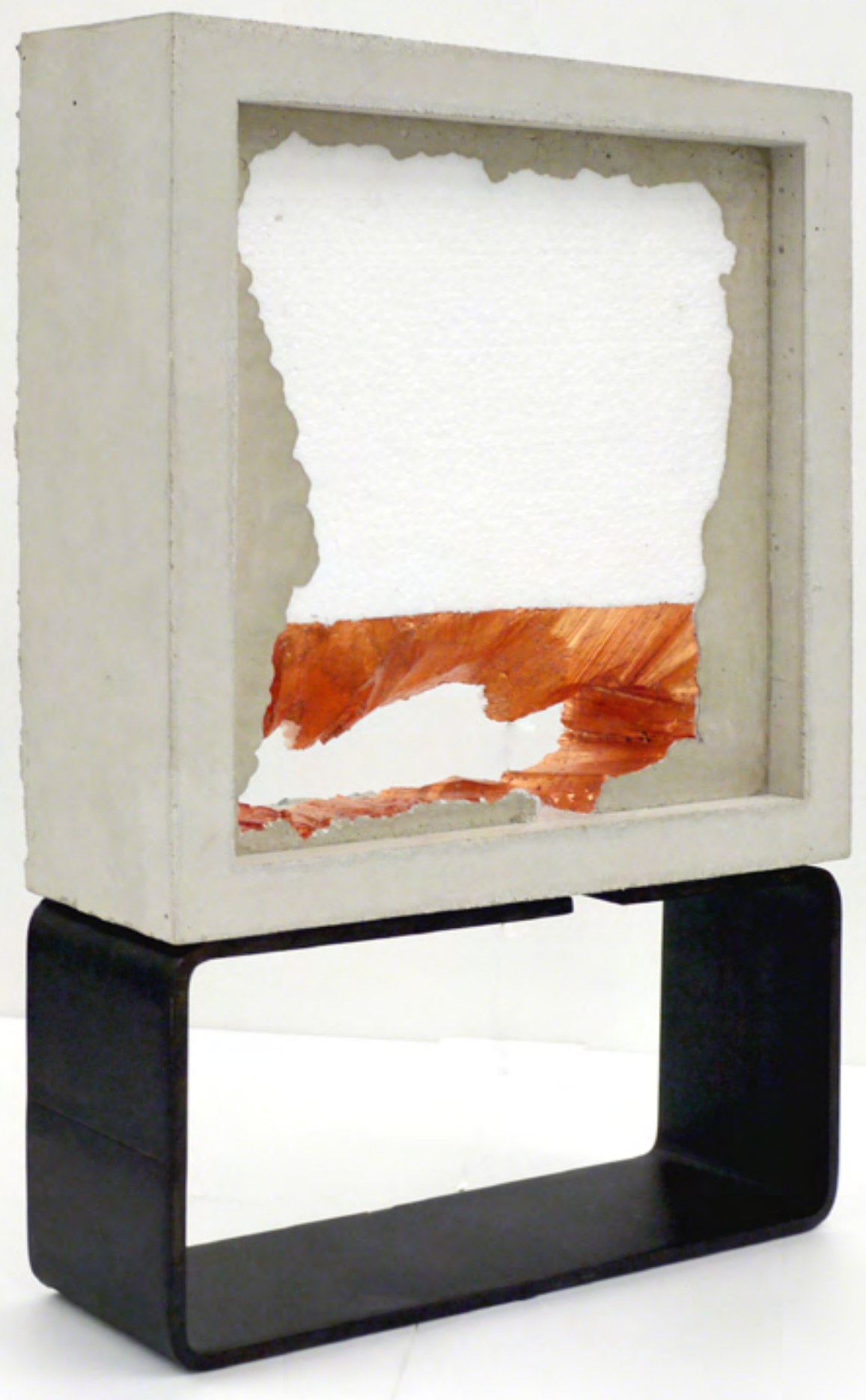




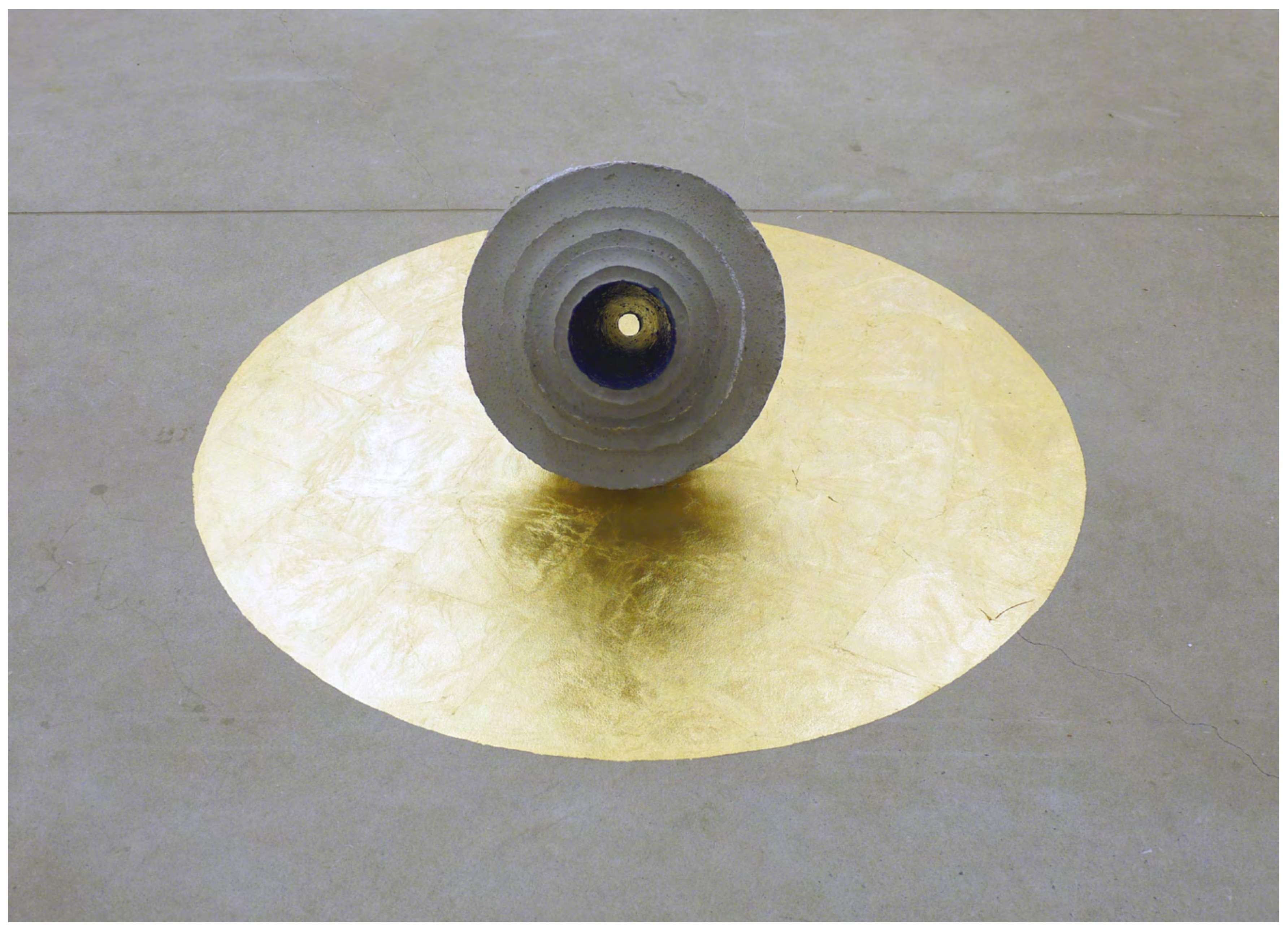




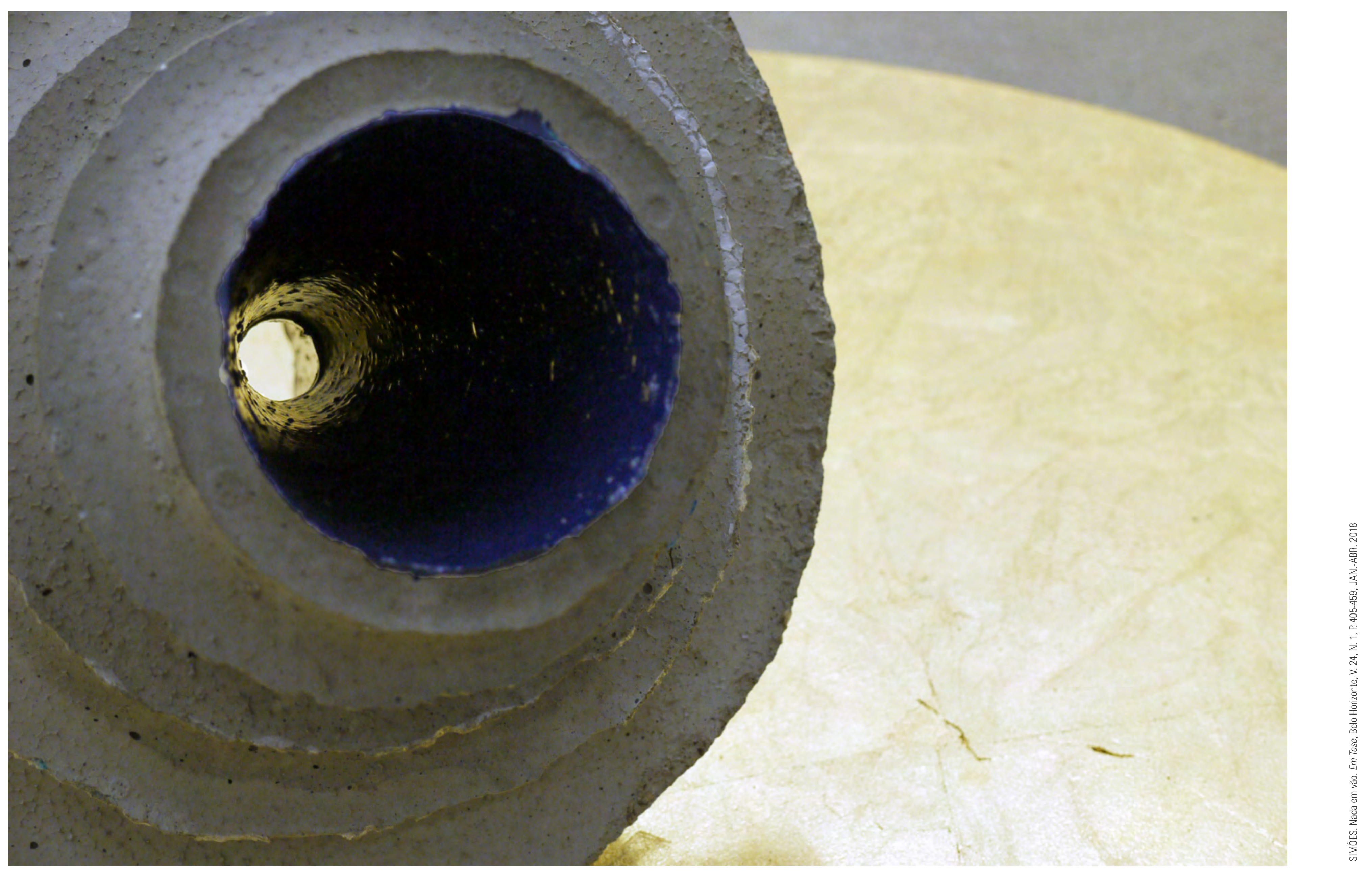




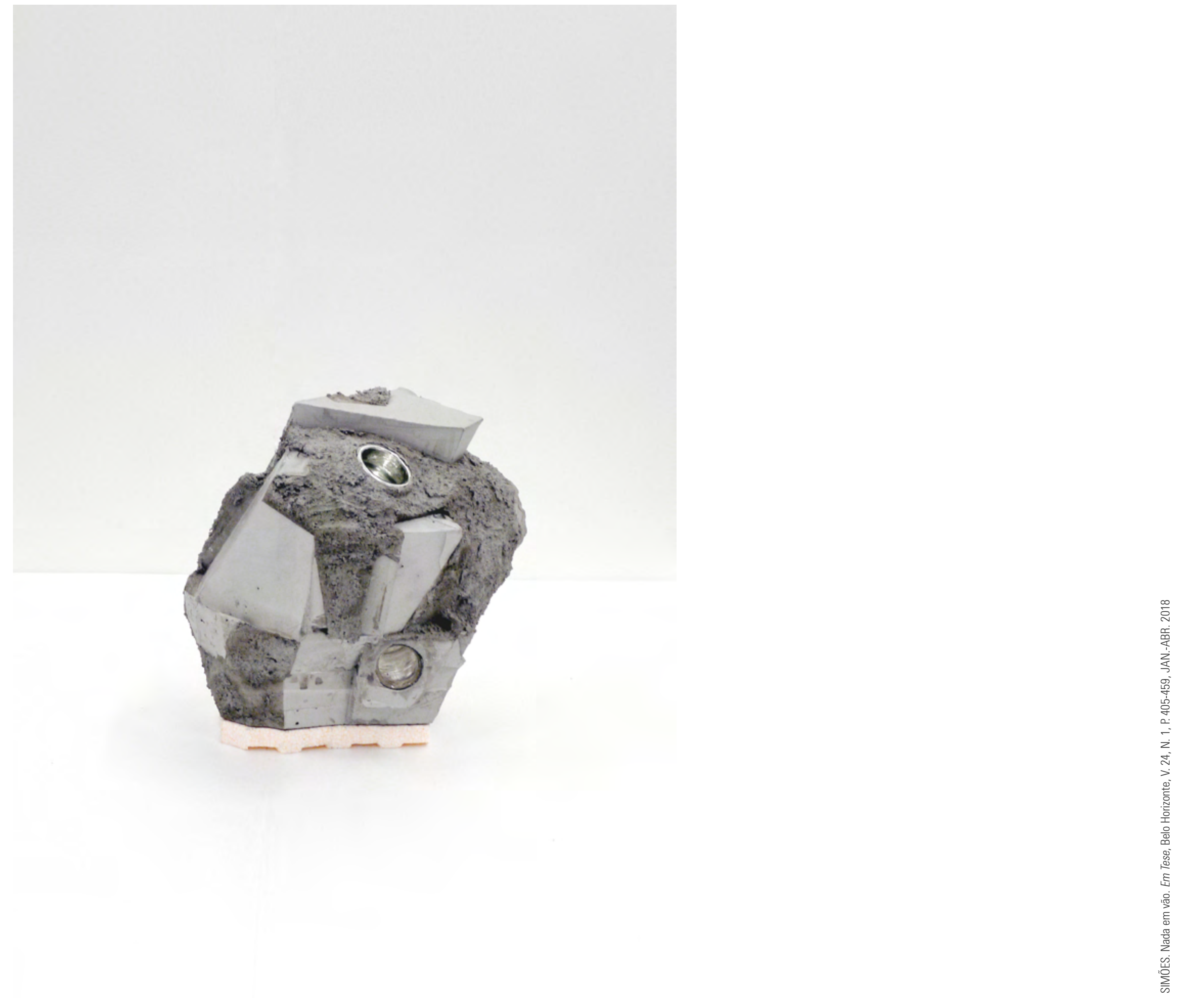




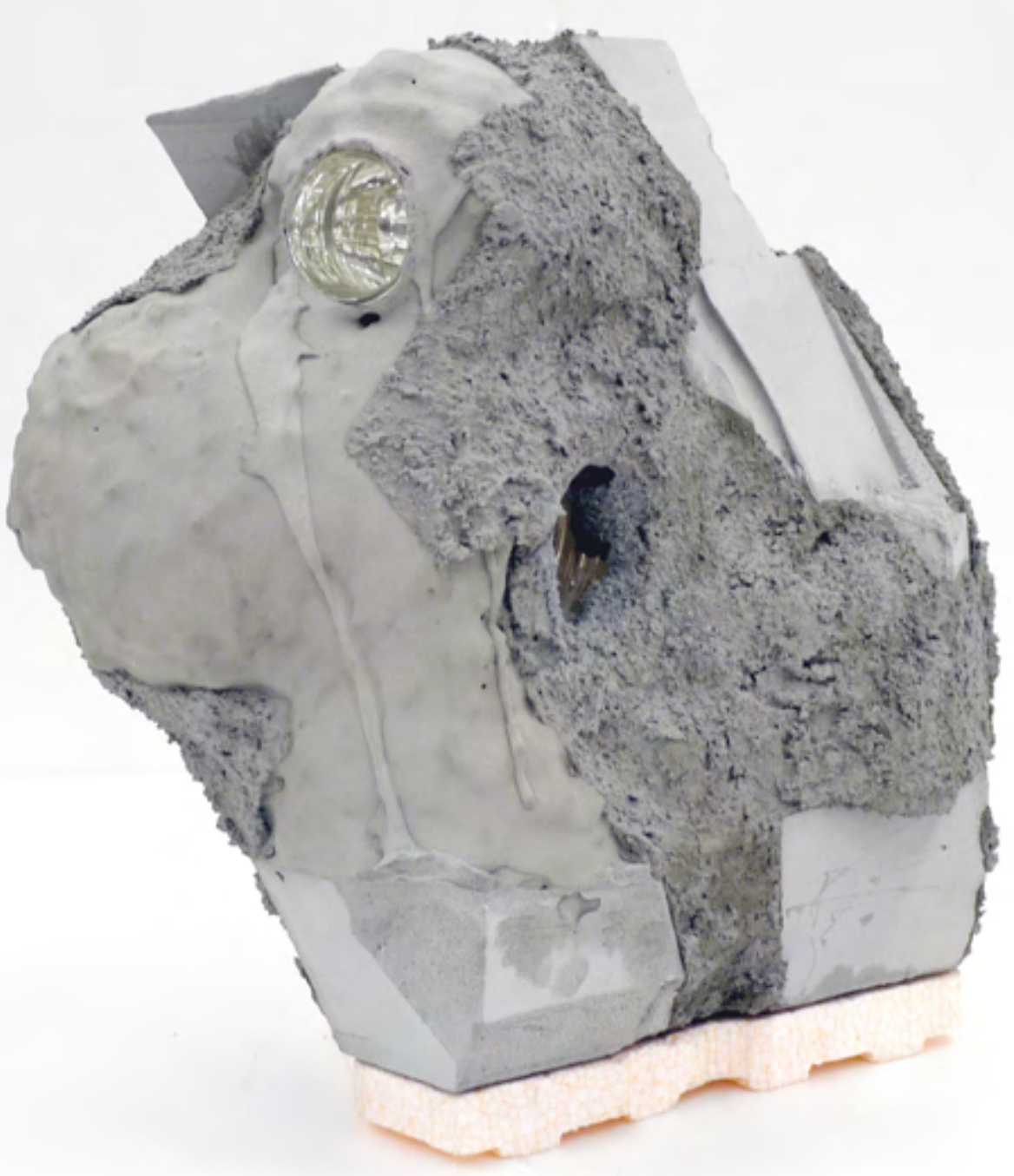




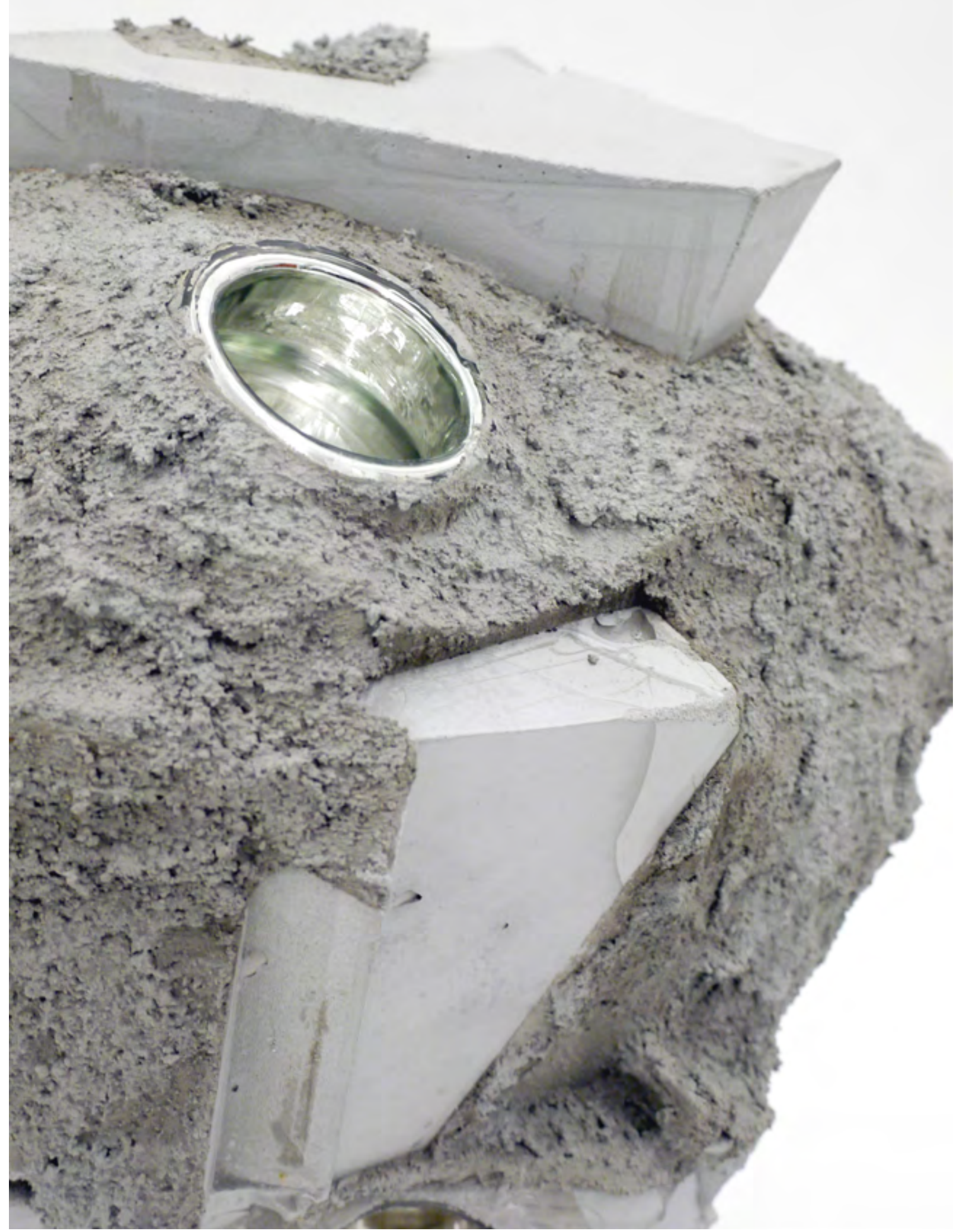




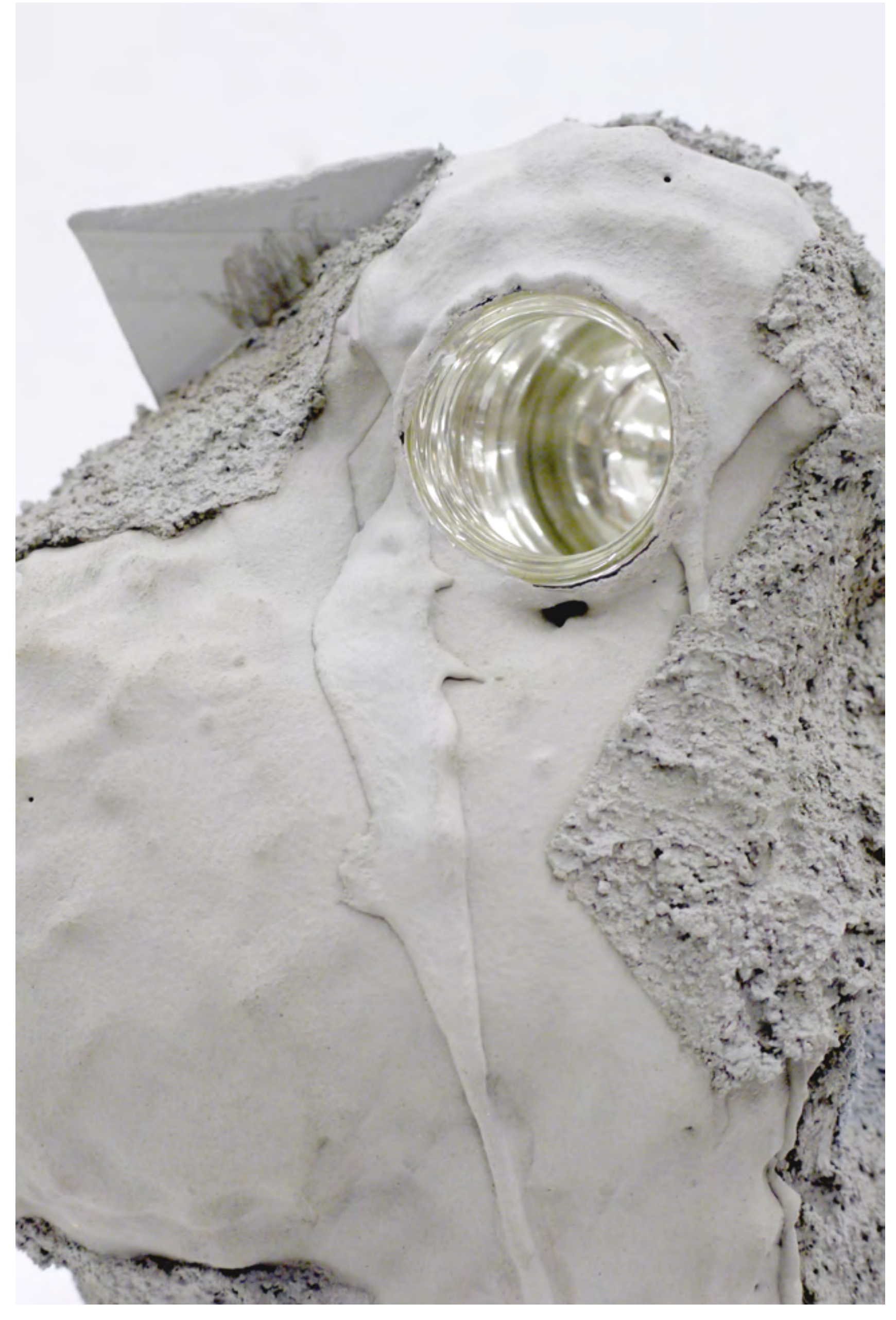




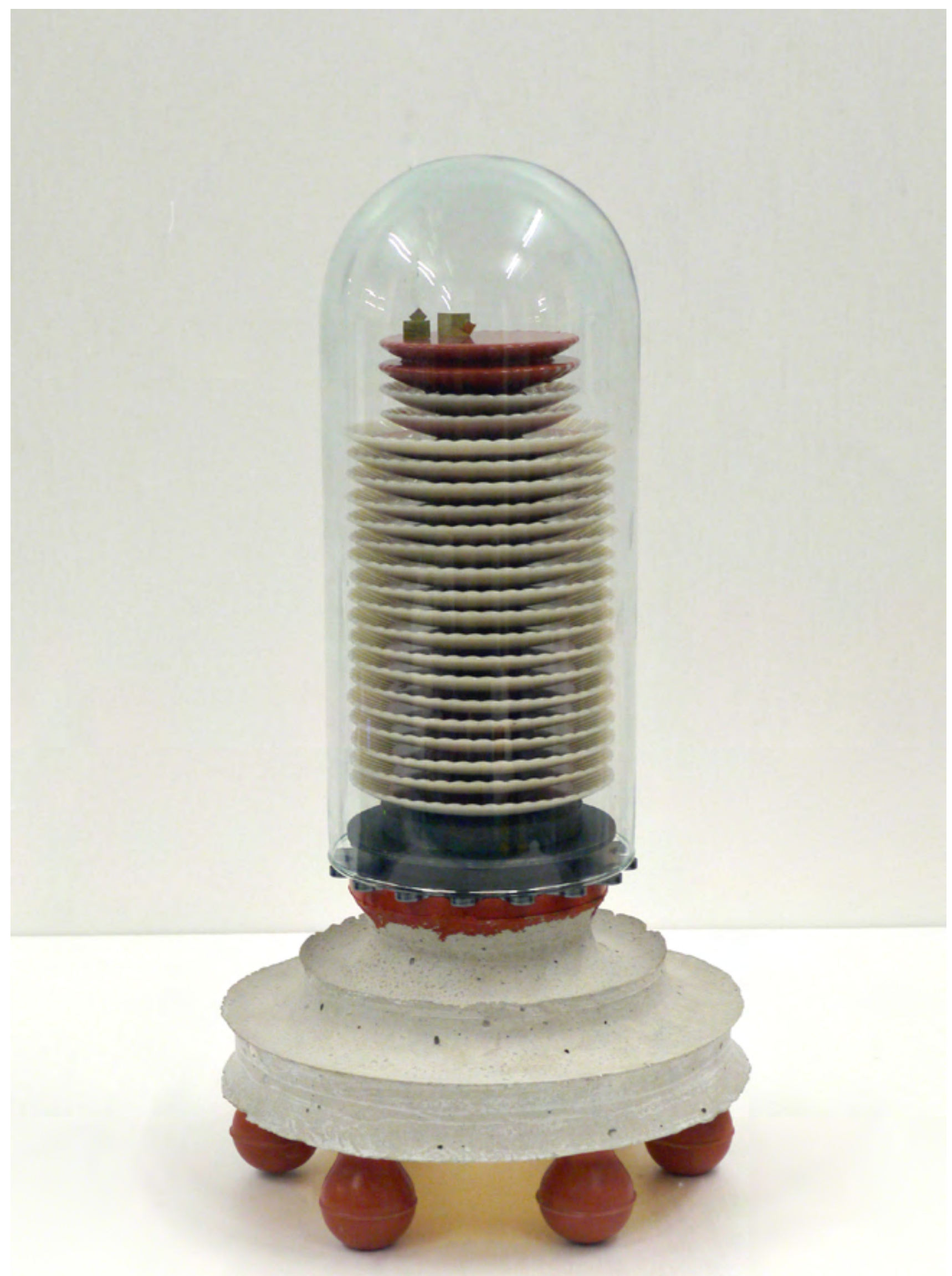




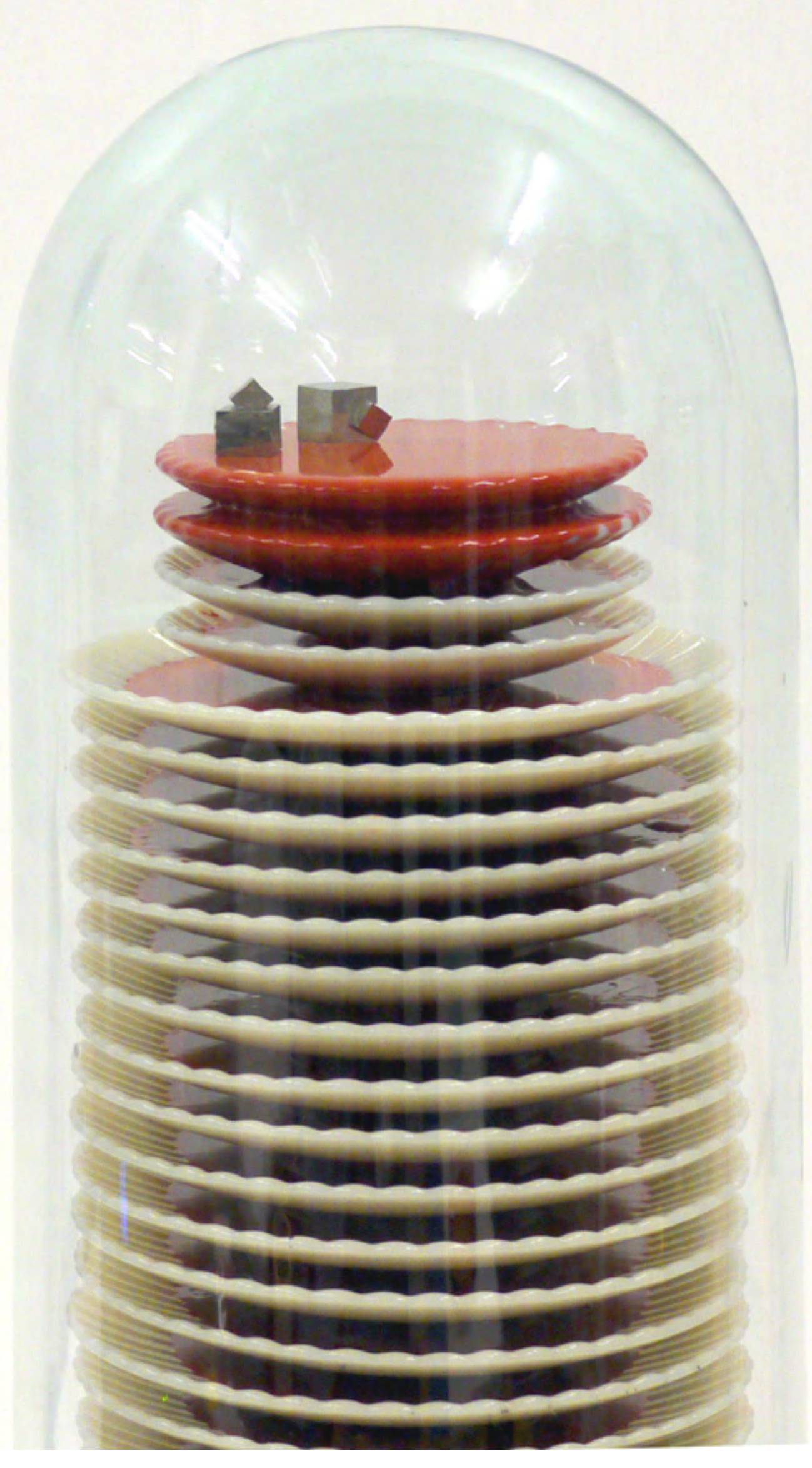


B 


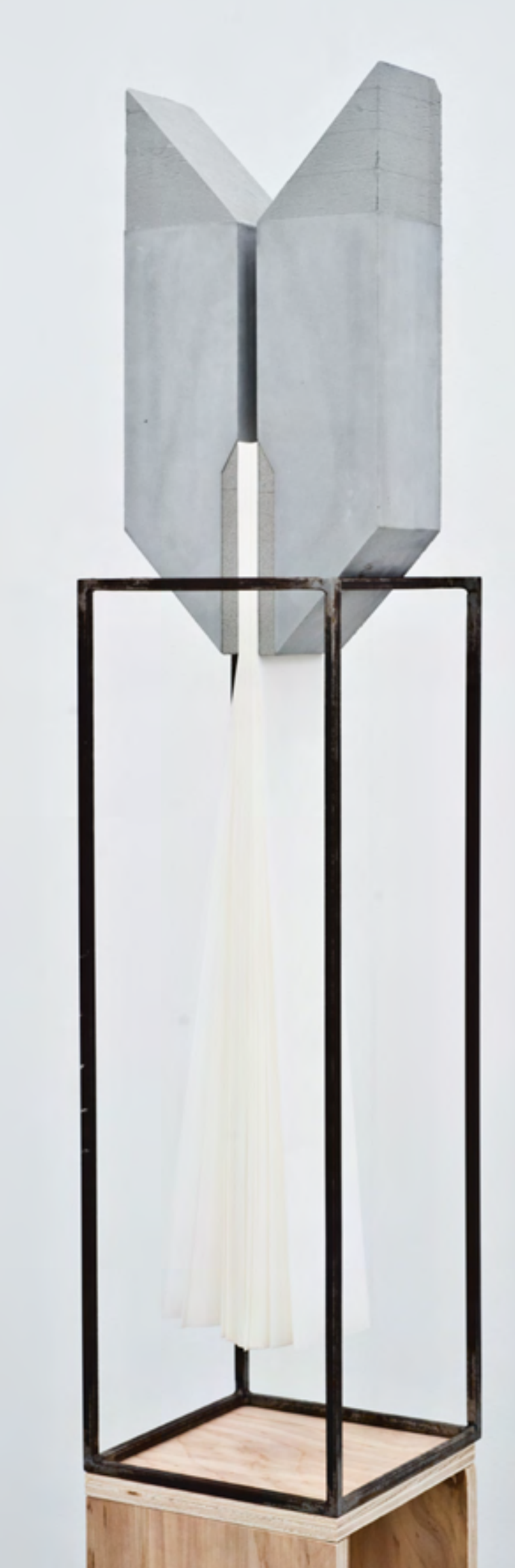




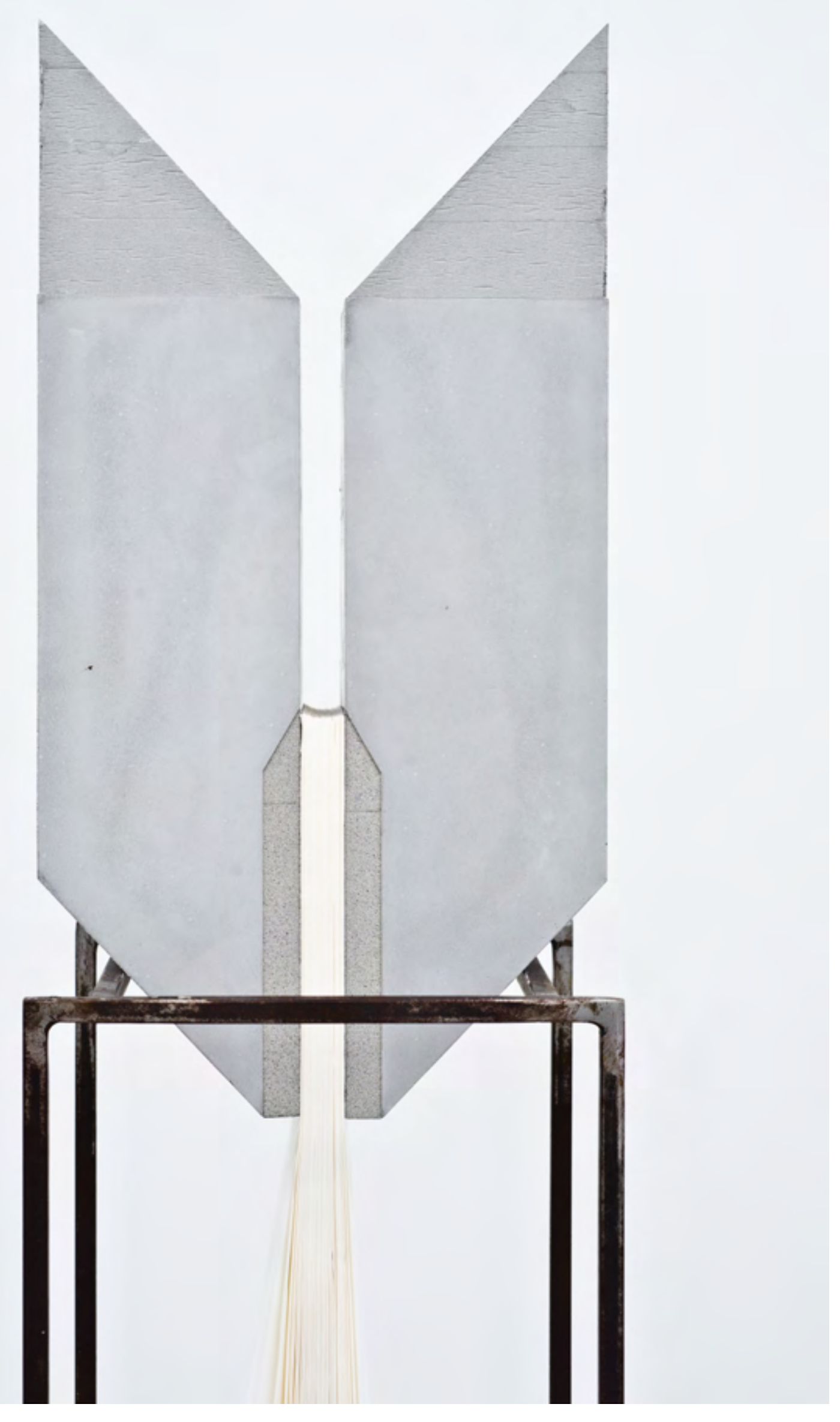




$$
\frac{1}{\pi}
$$




$$
\text { i }
$$




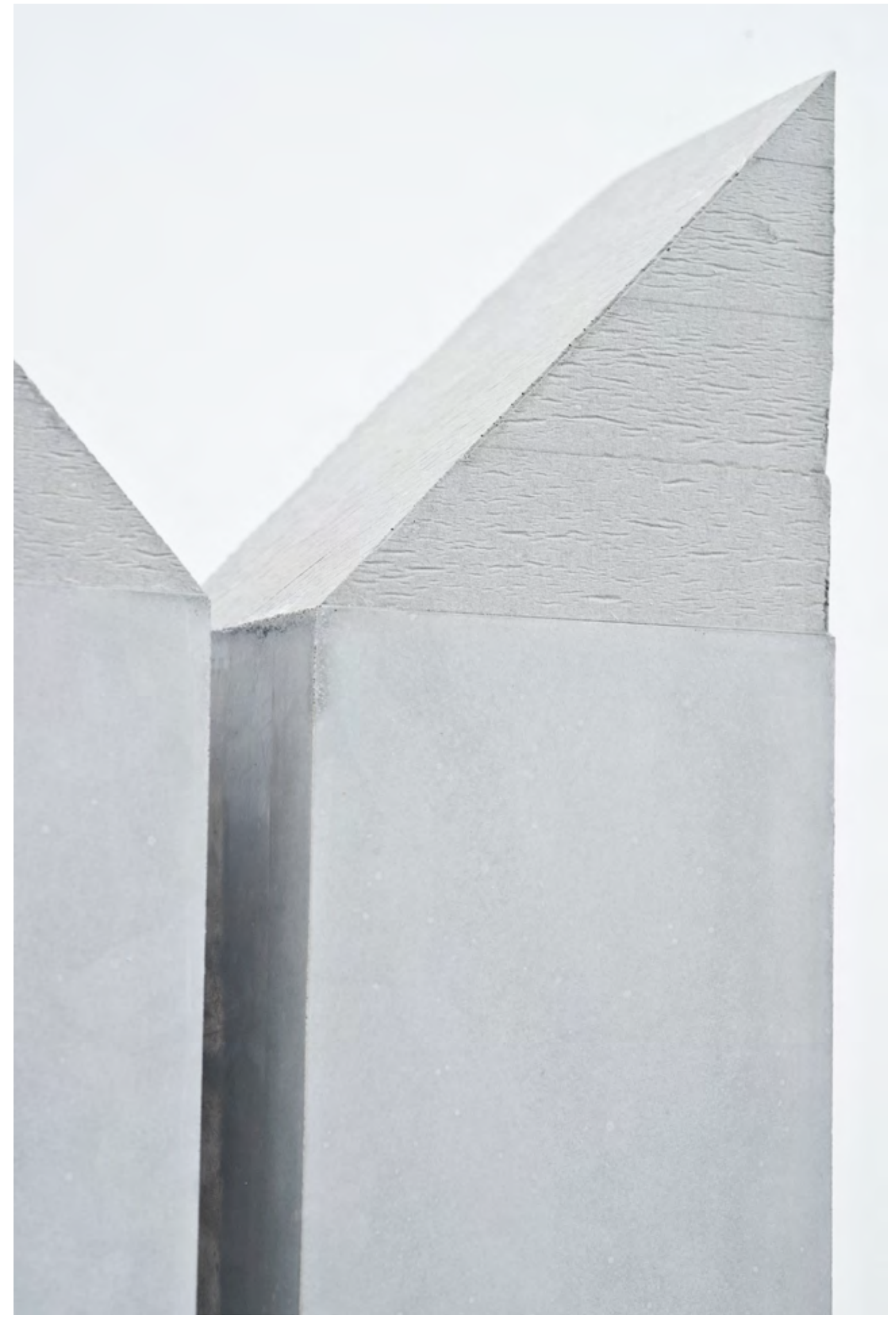




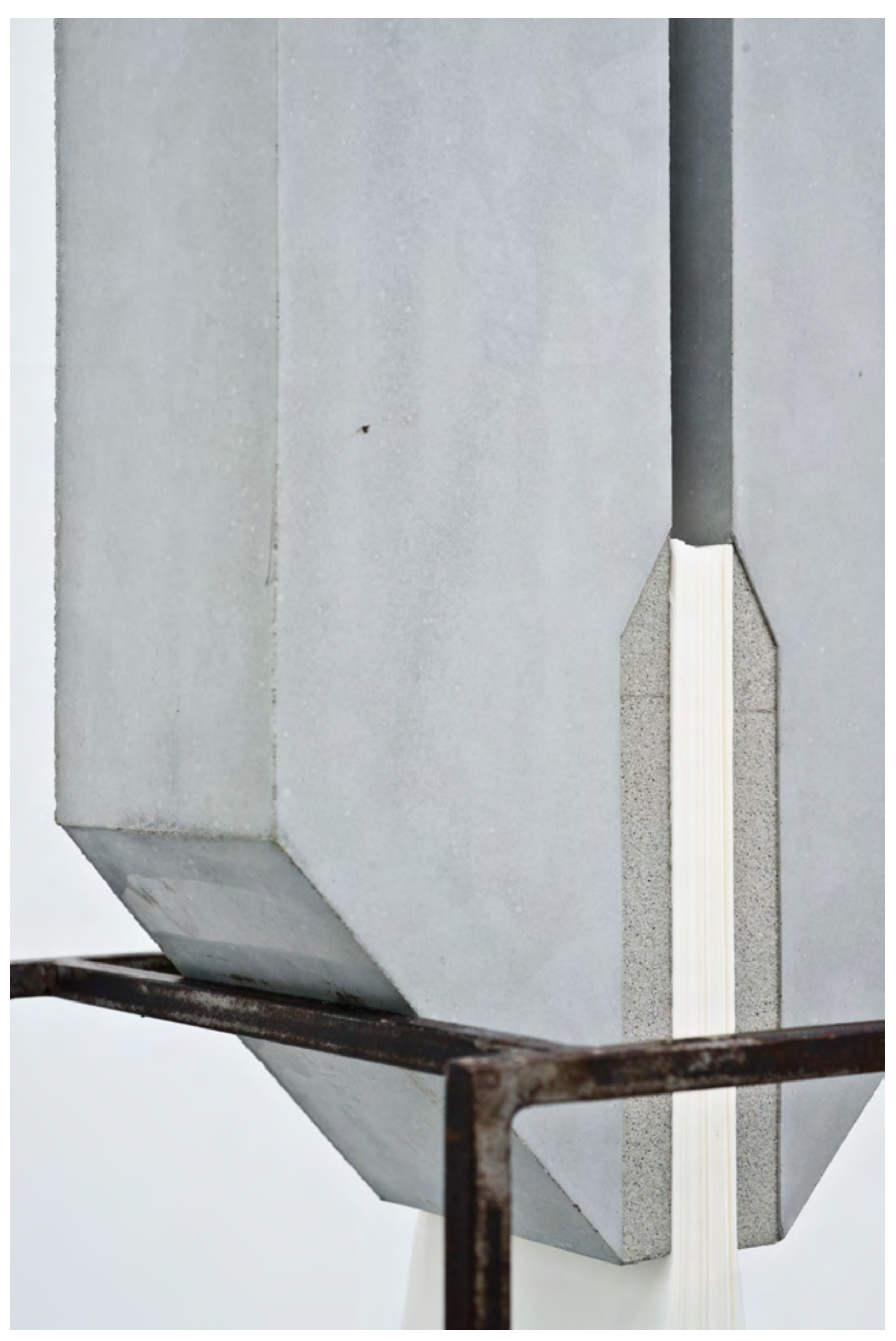




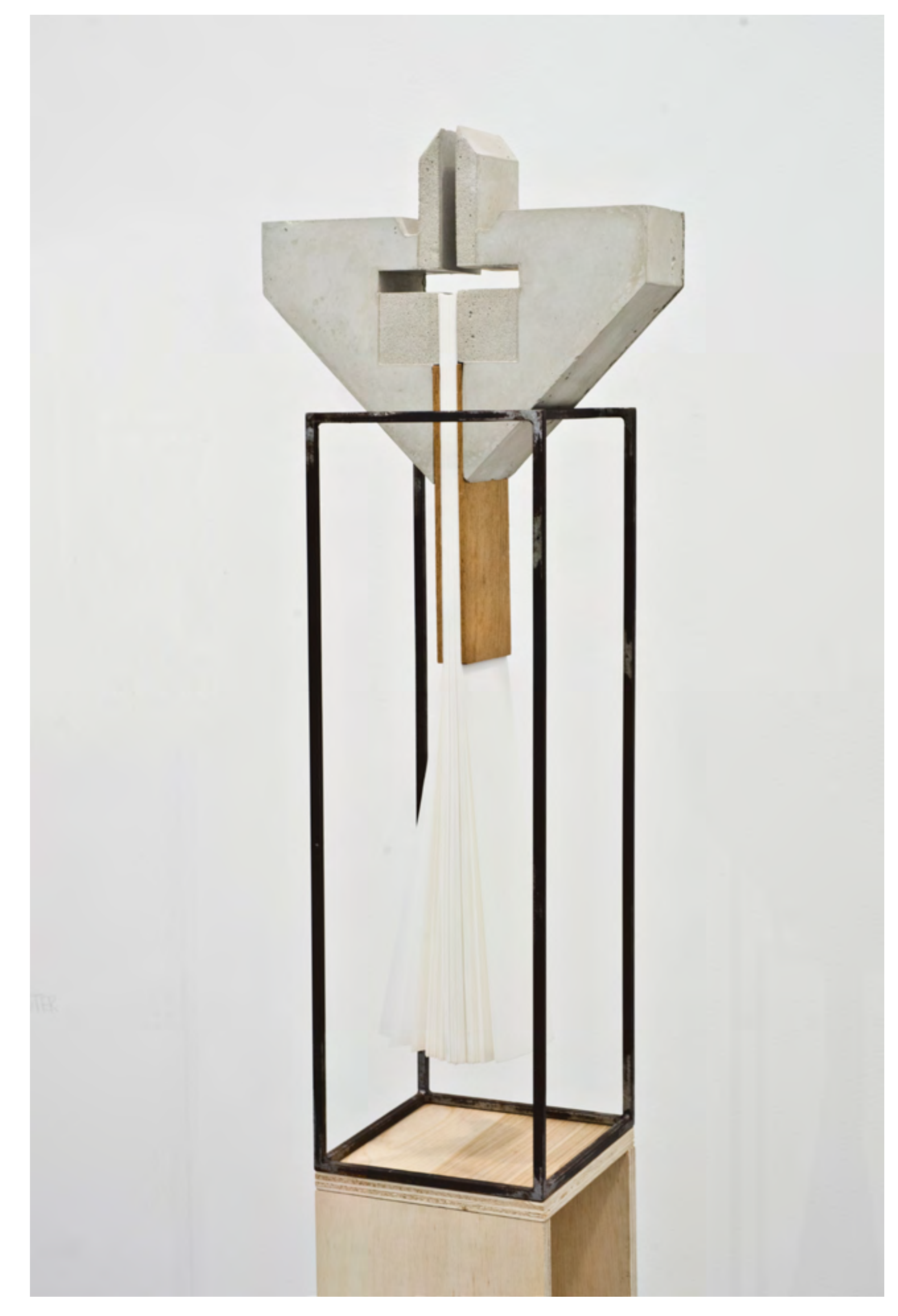




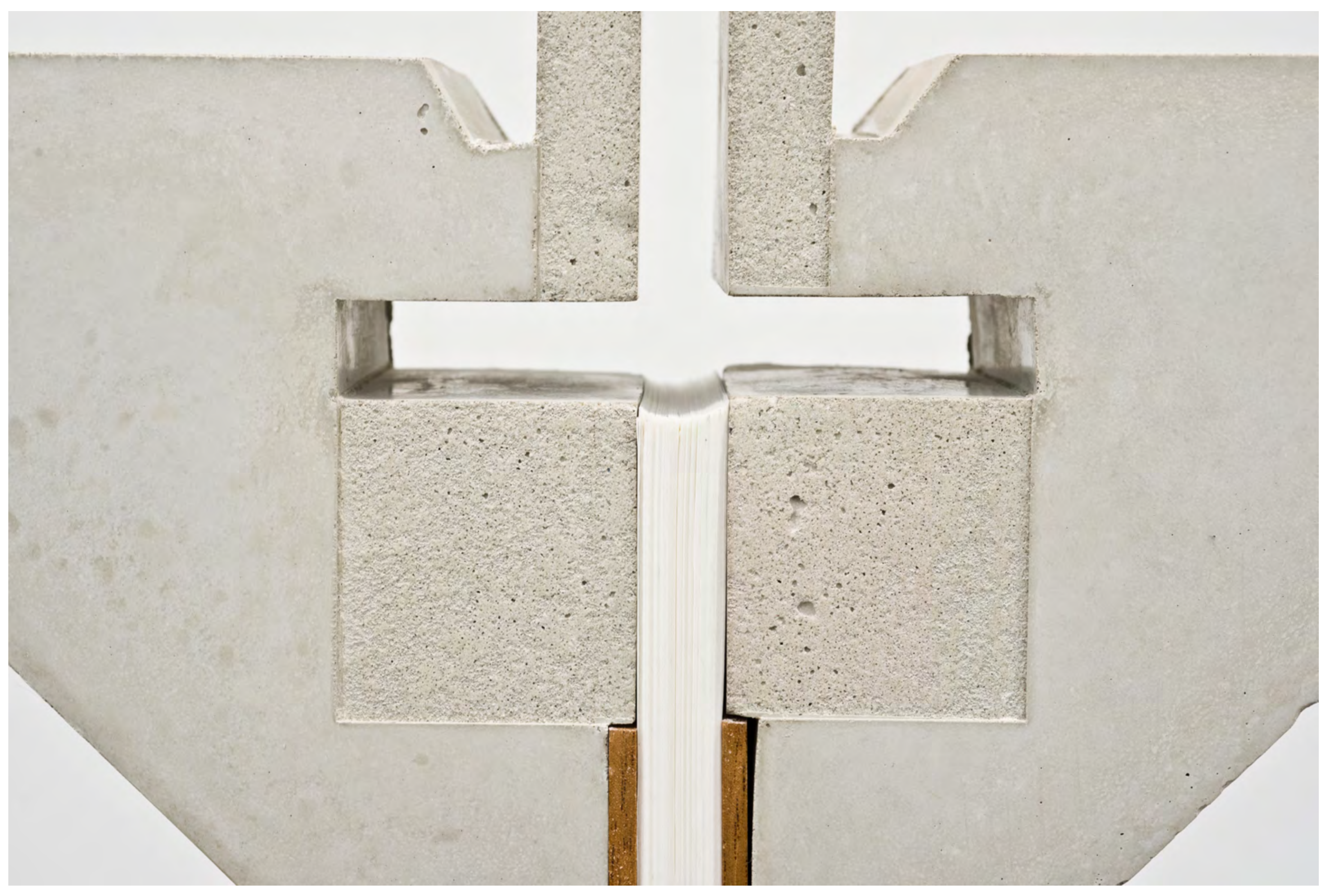




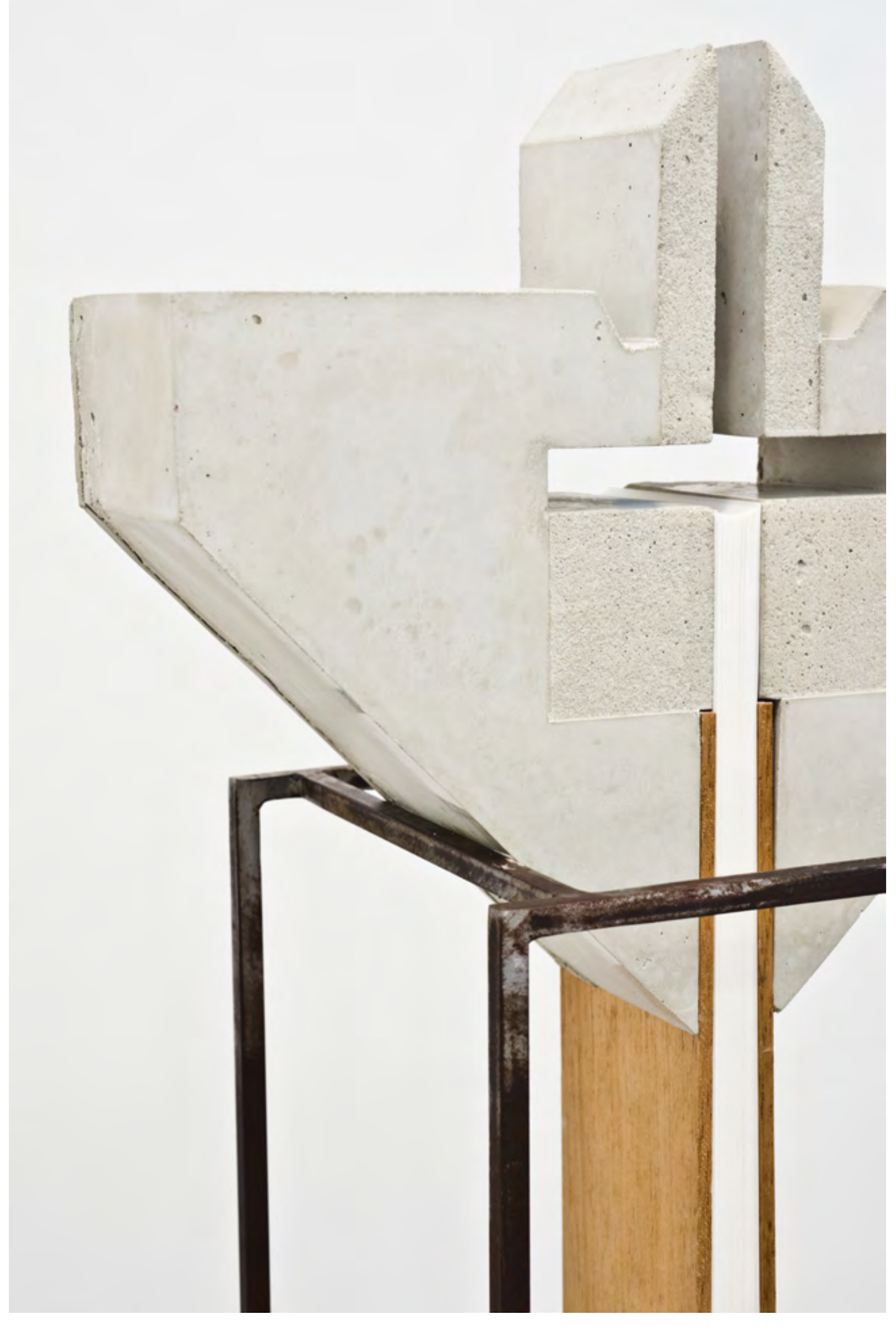


<smiles>CC#CC#CC</smiles> 


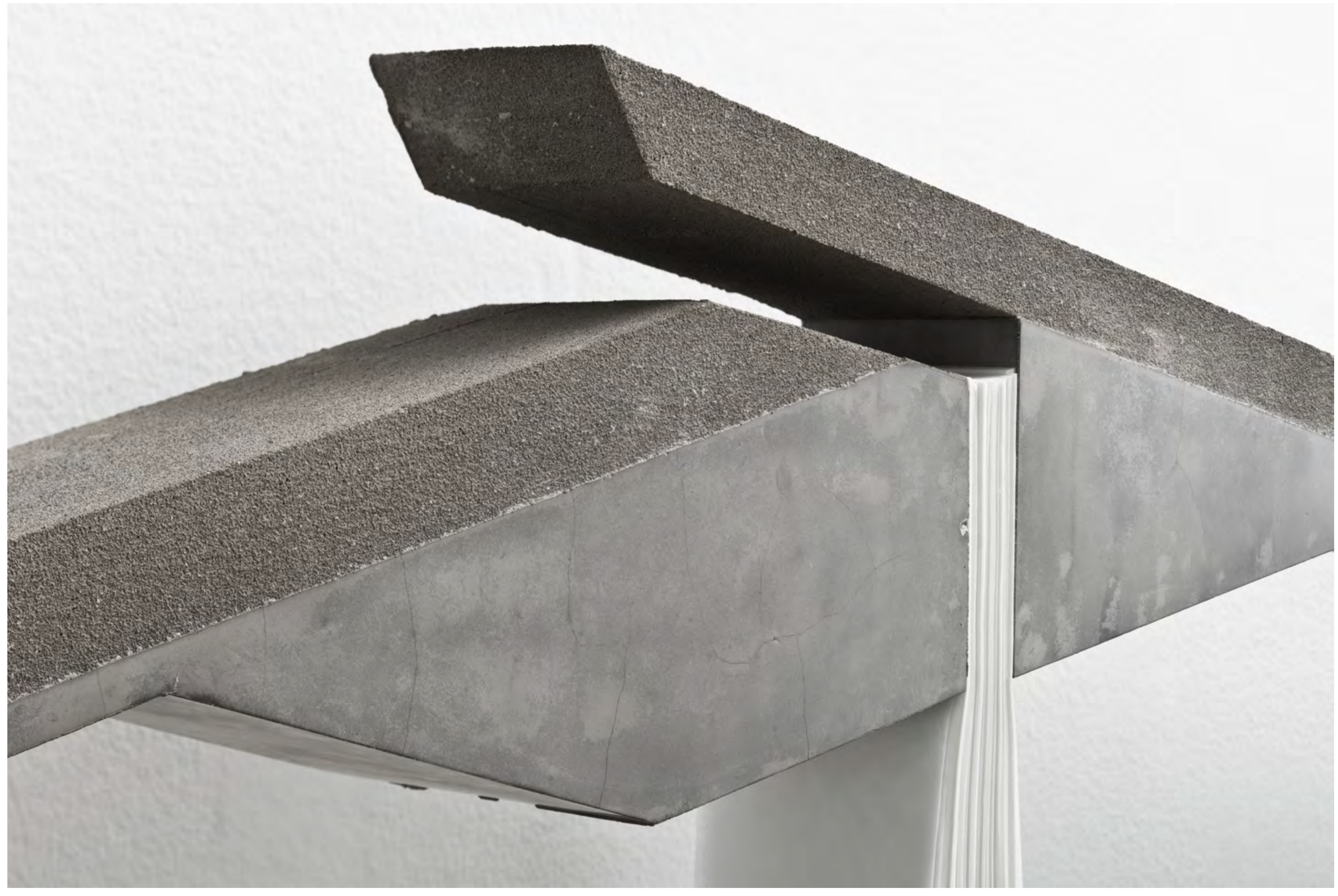




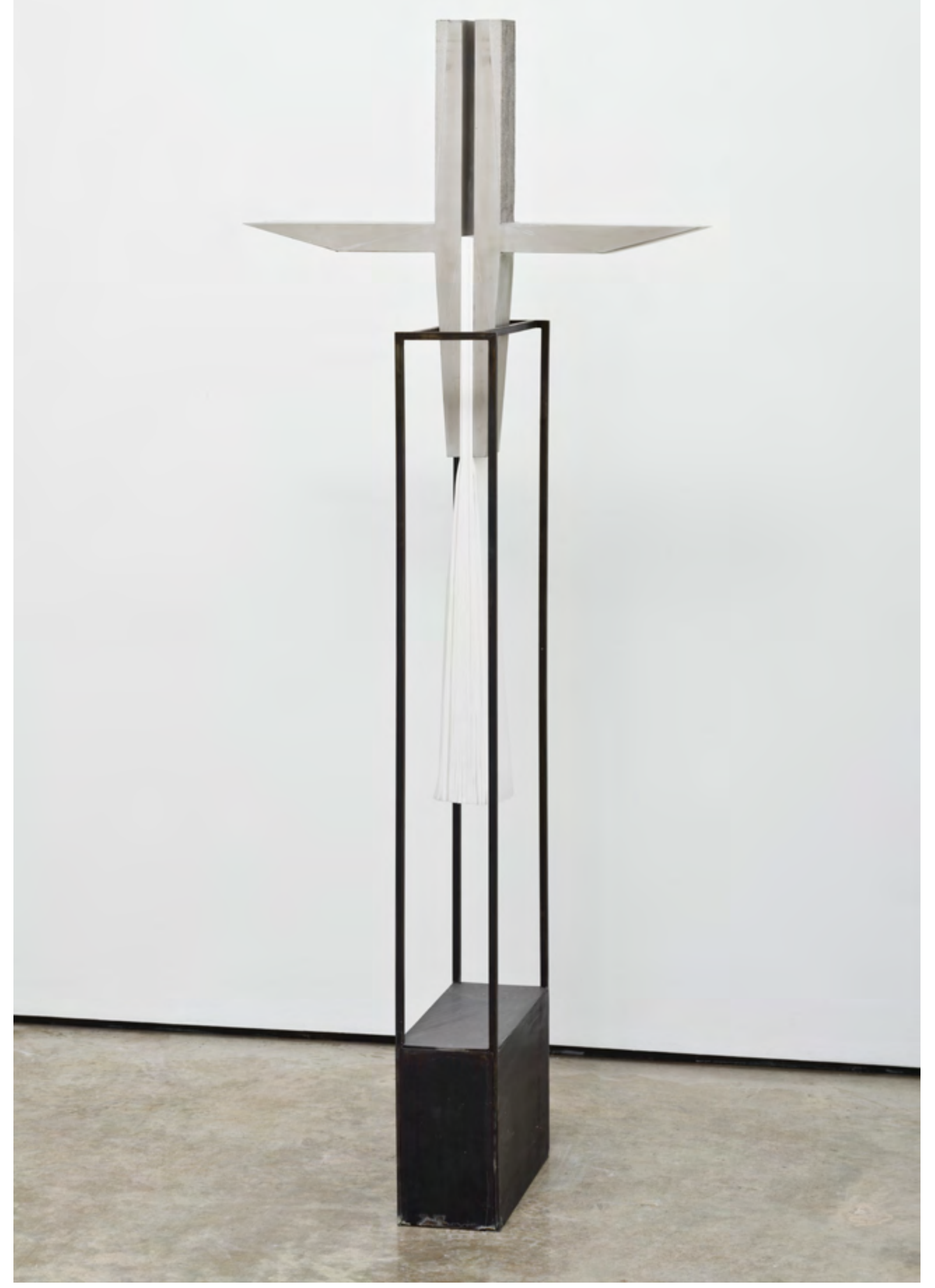








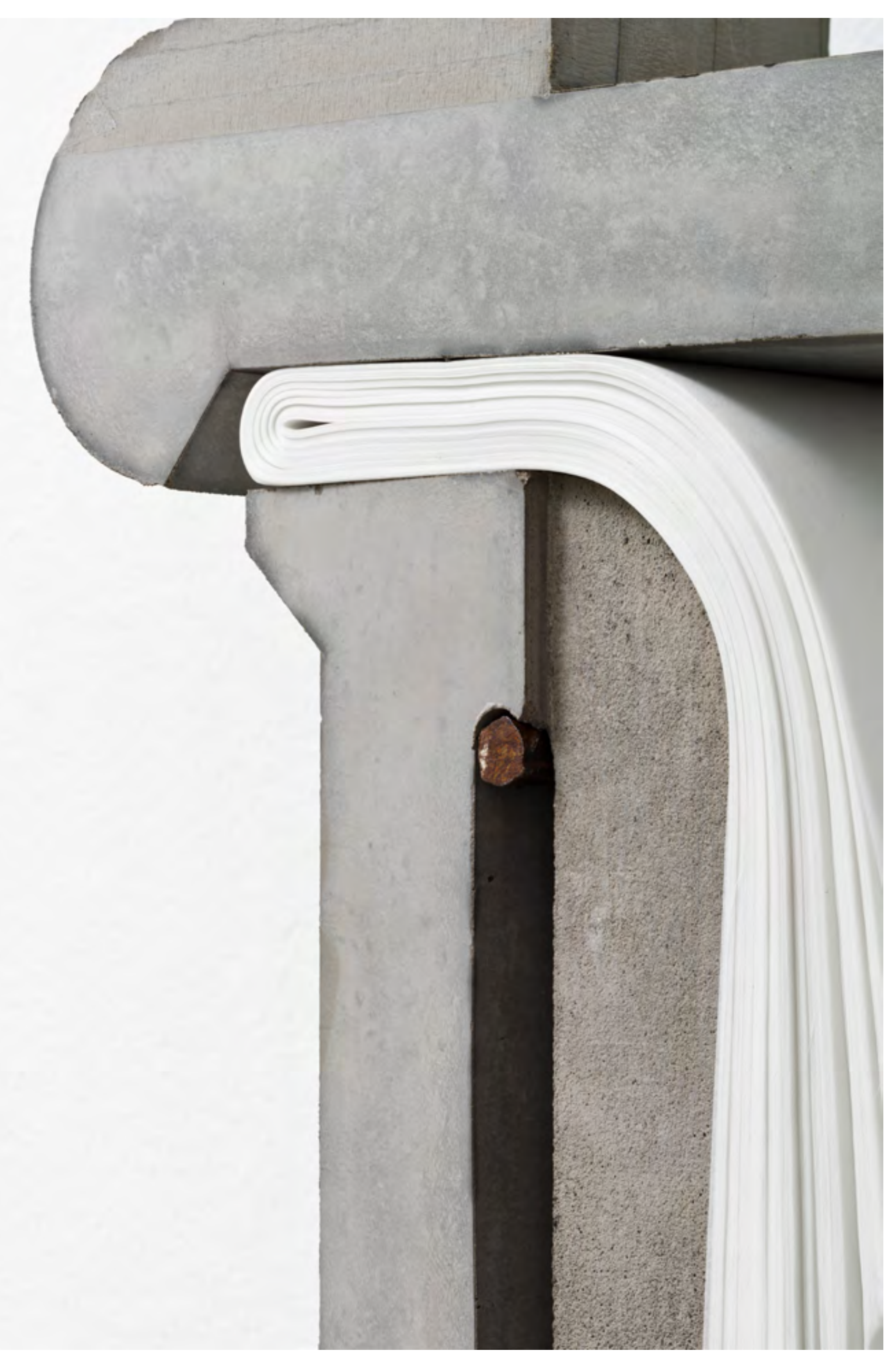




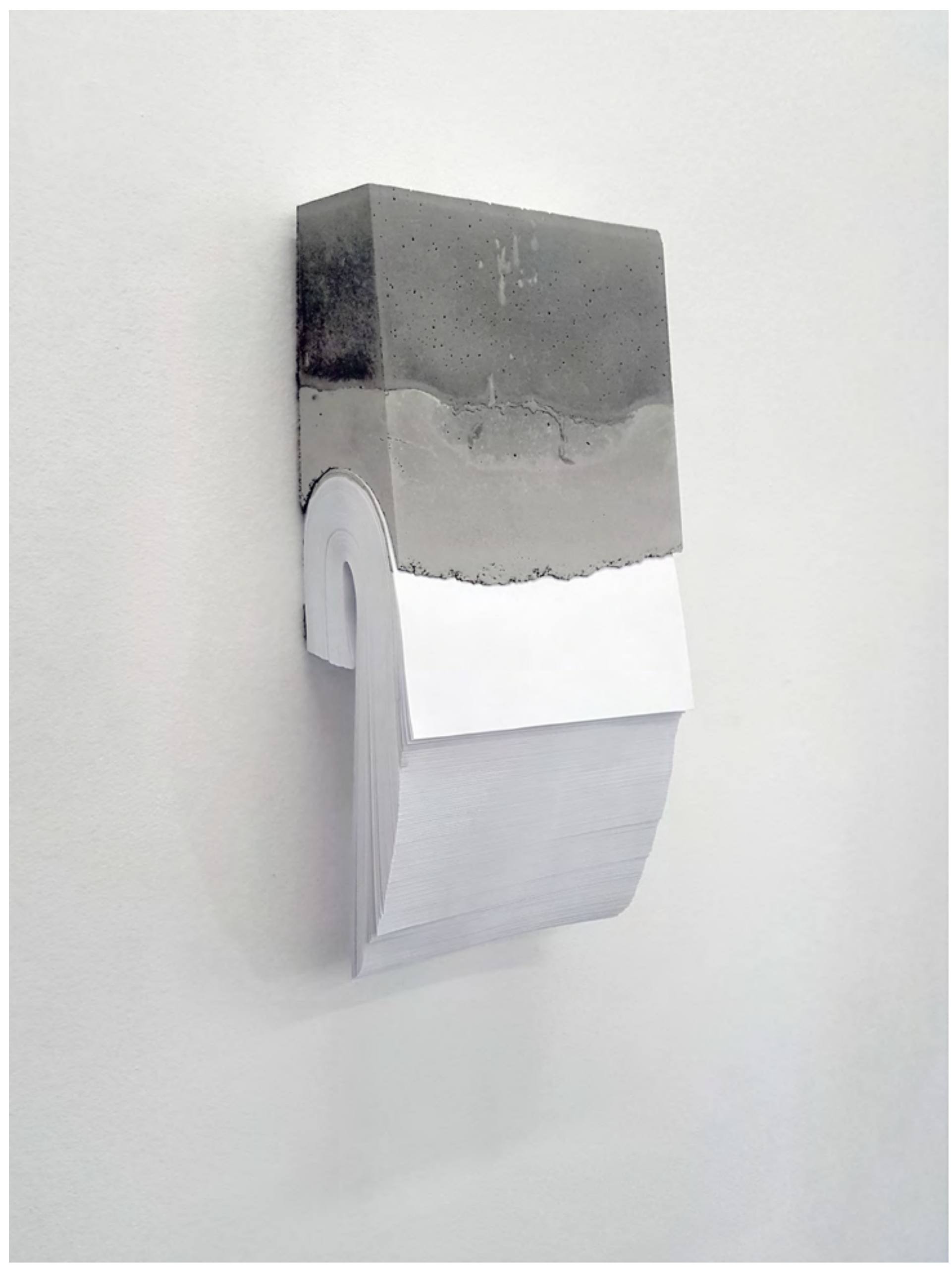




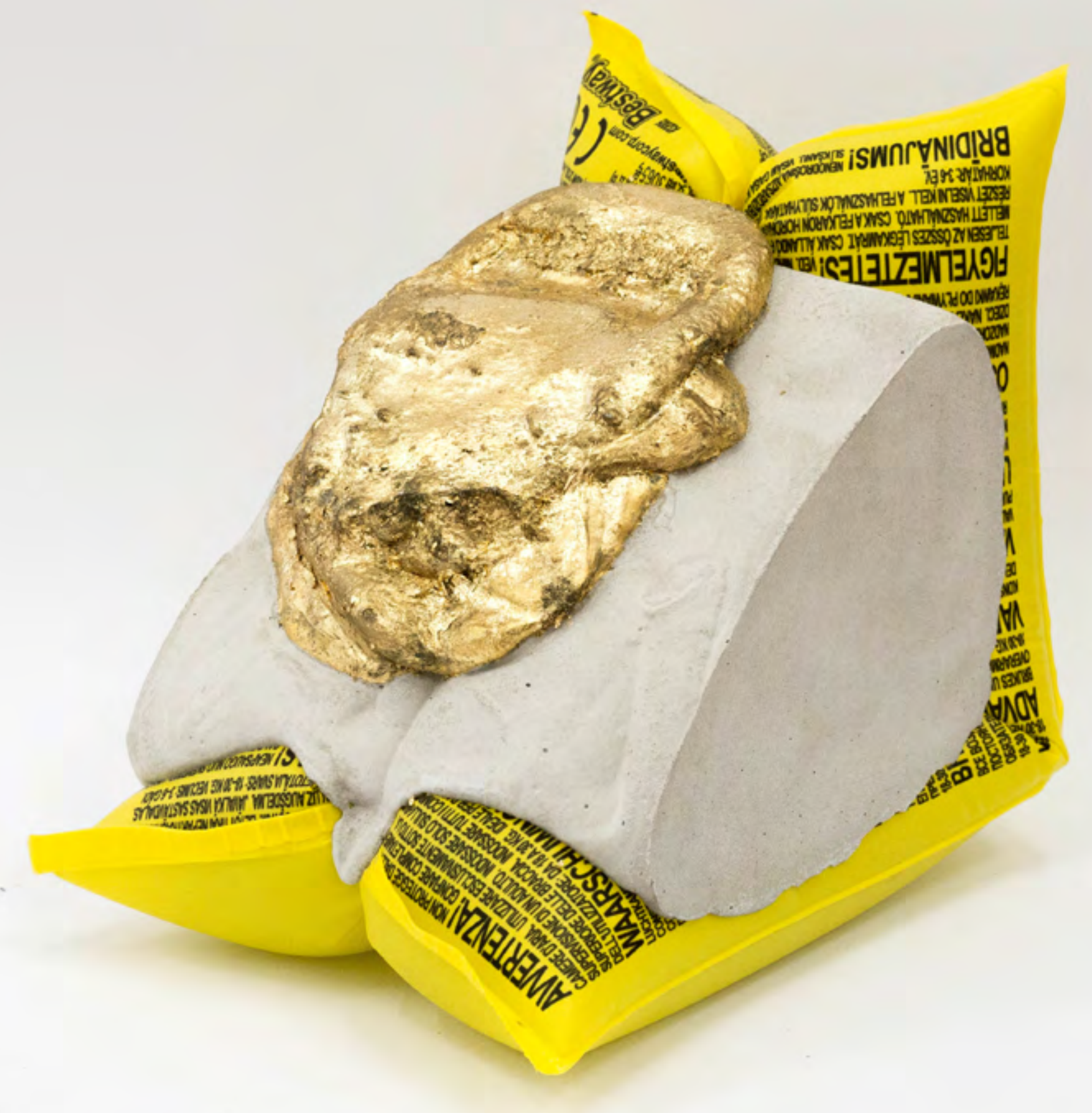







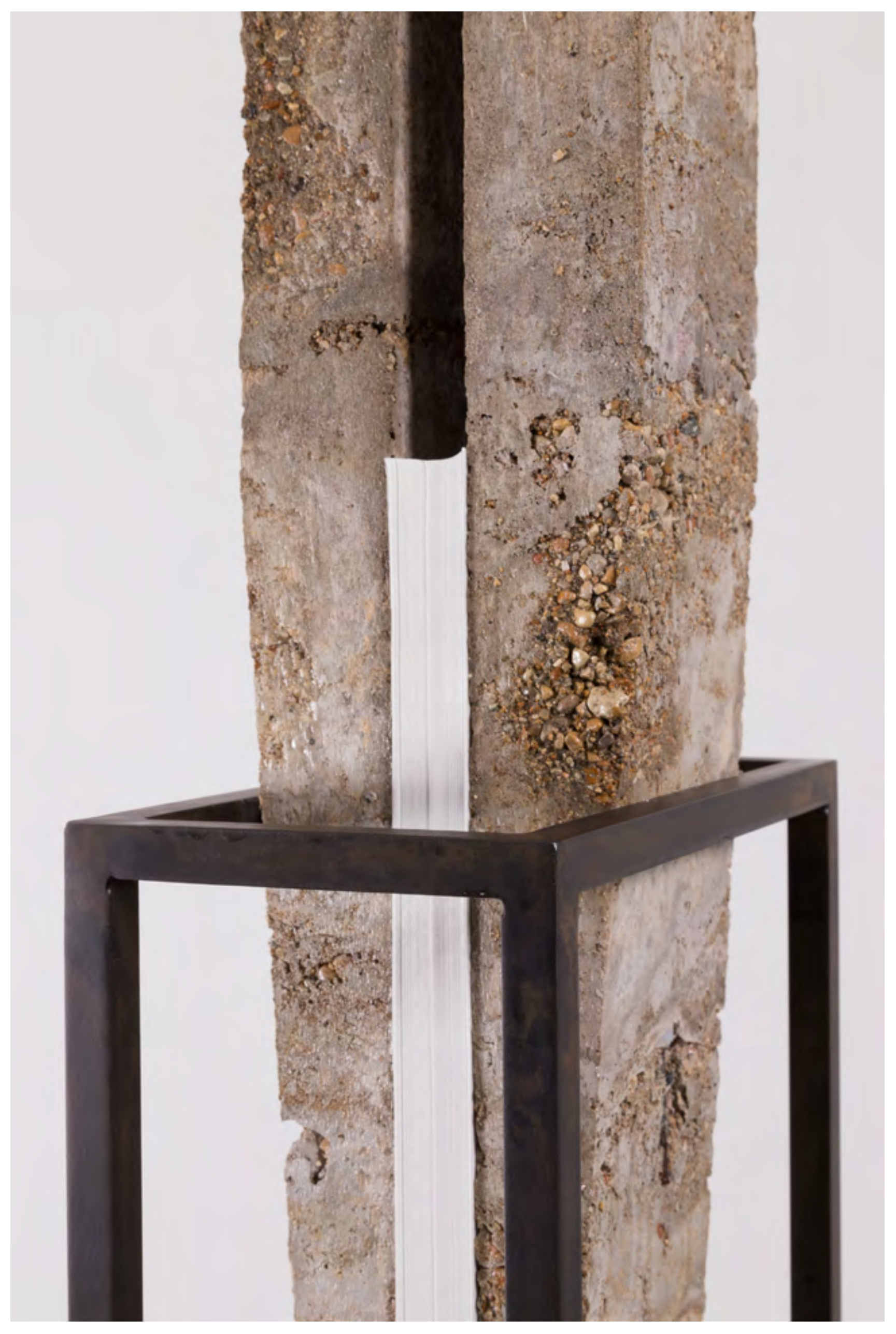




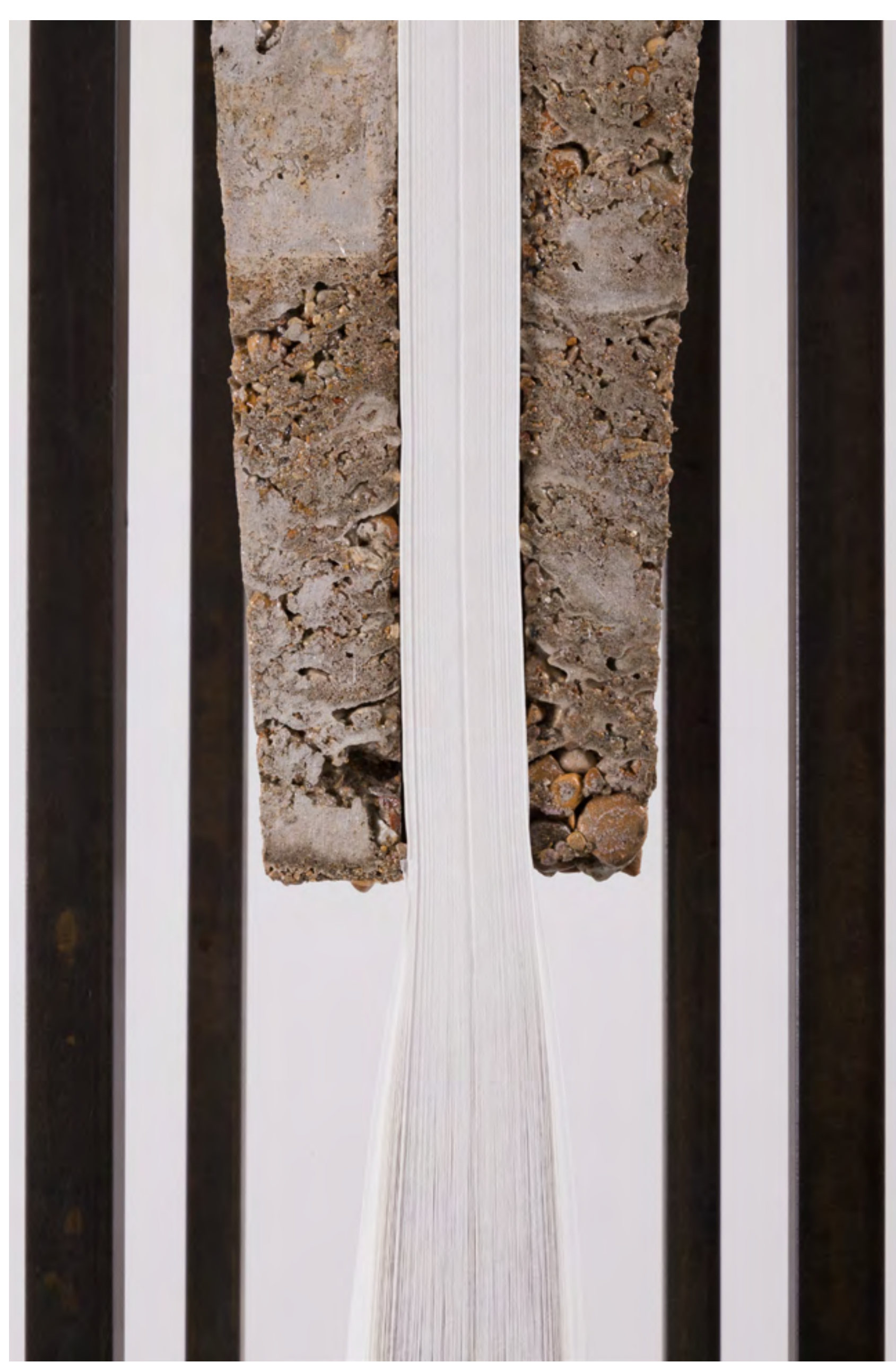




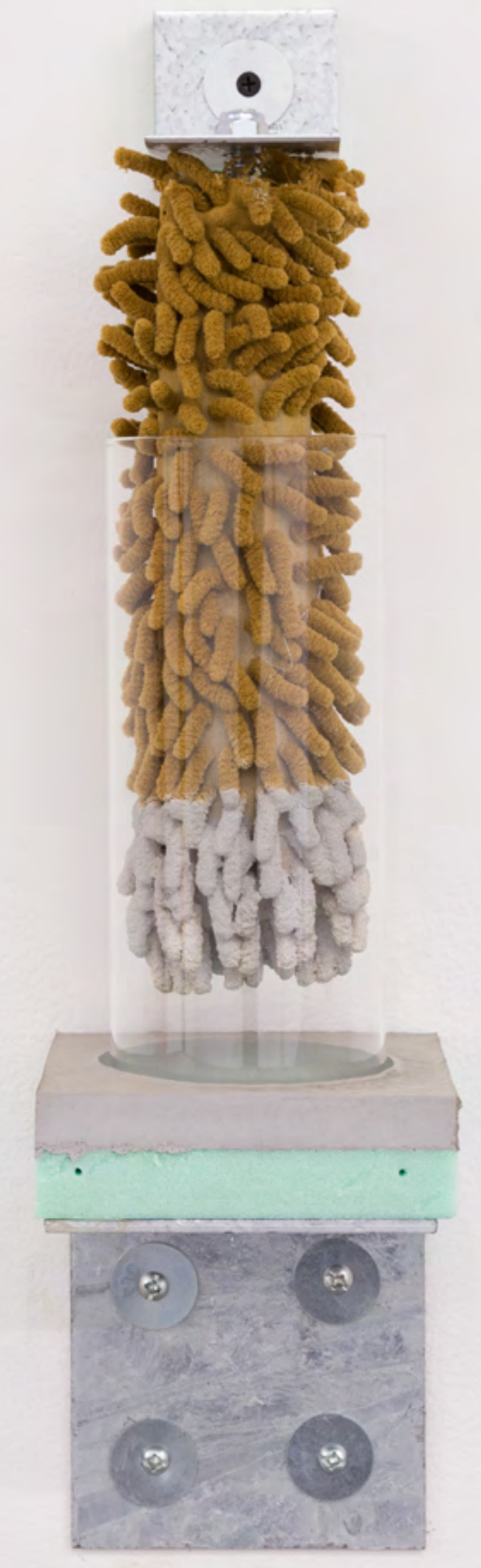




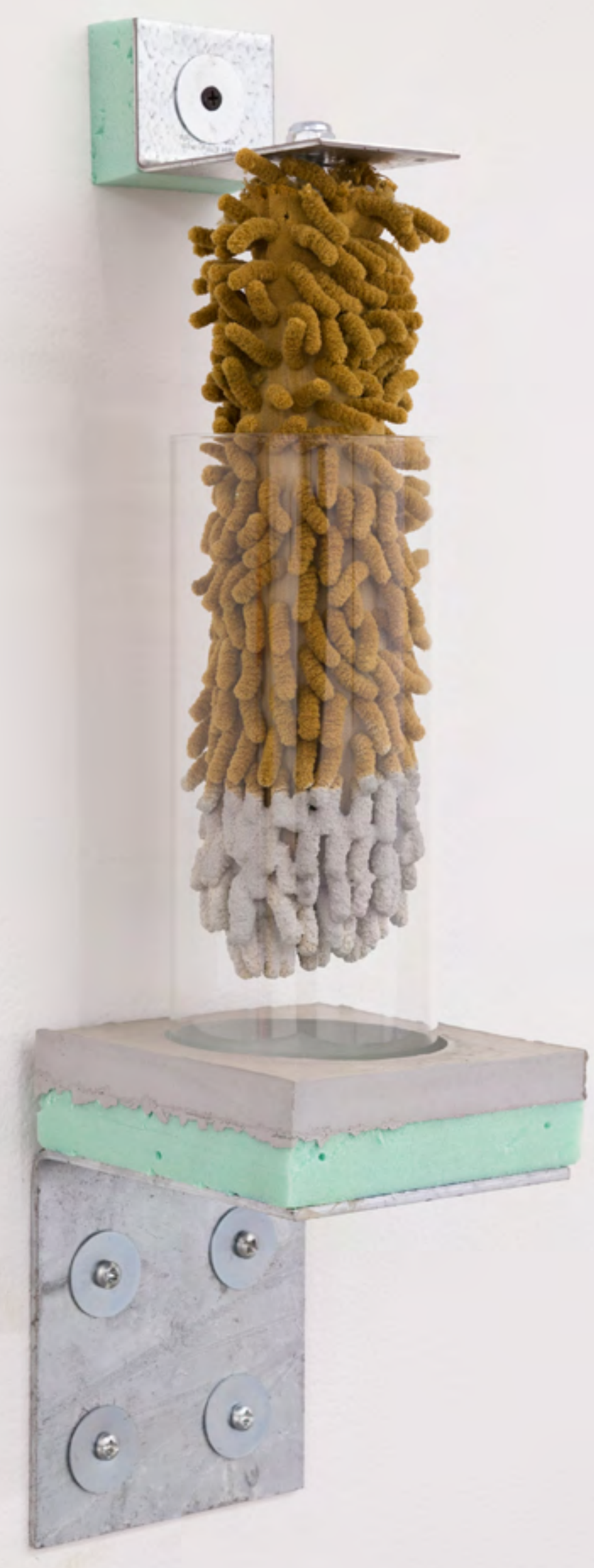




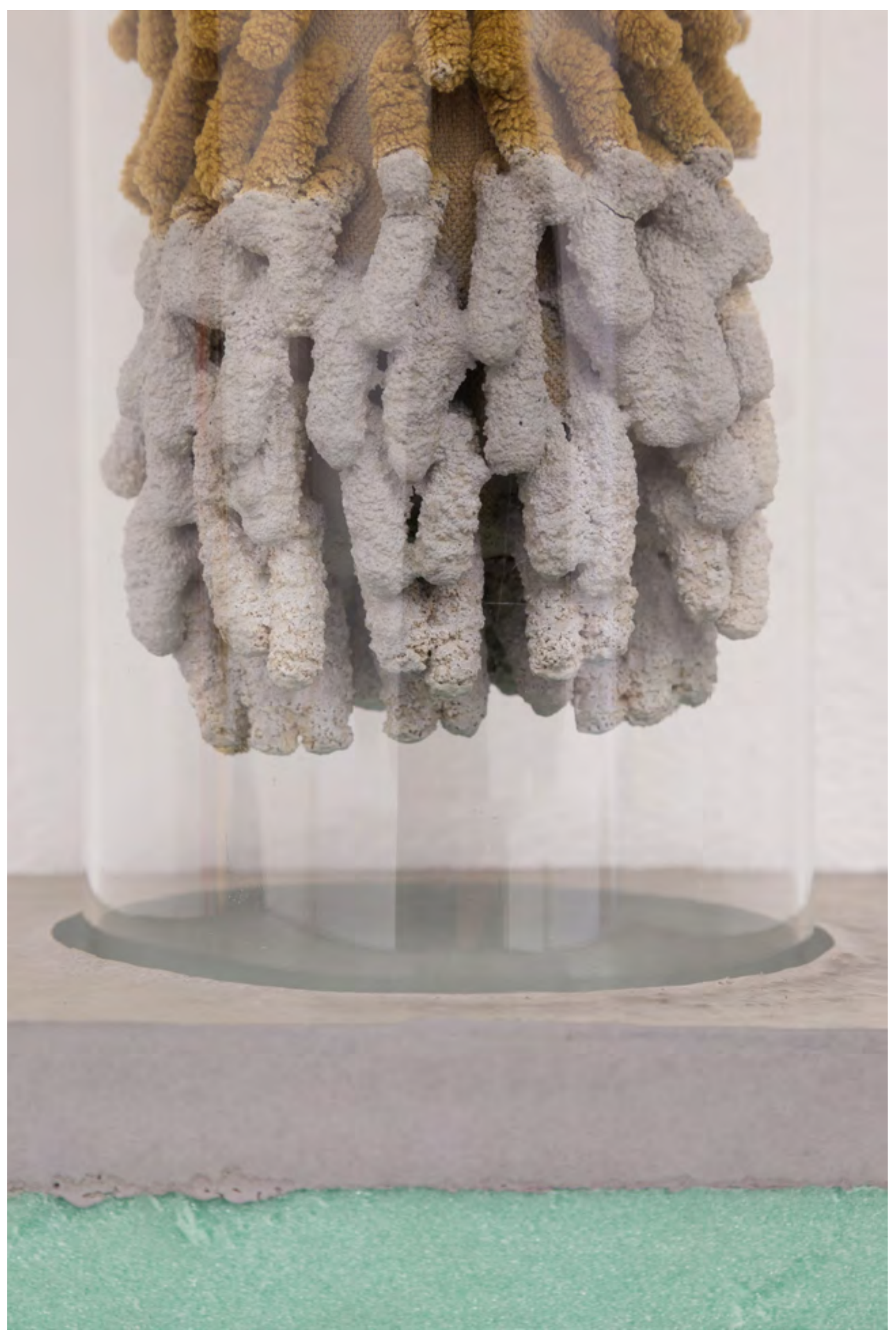




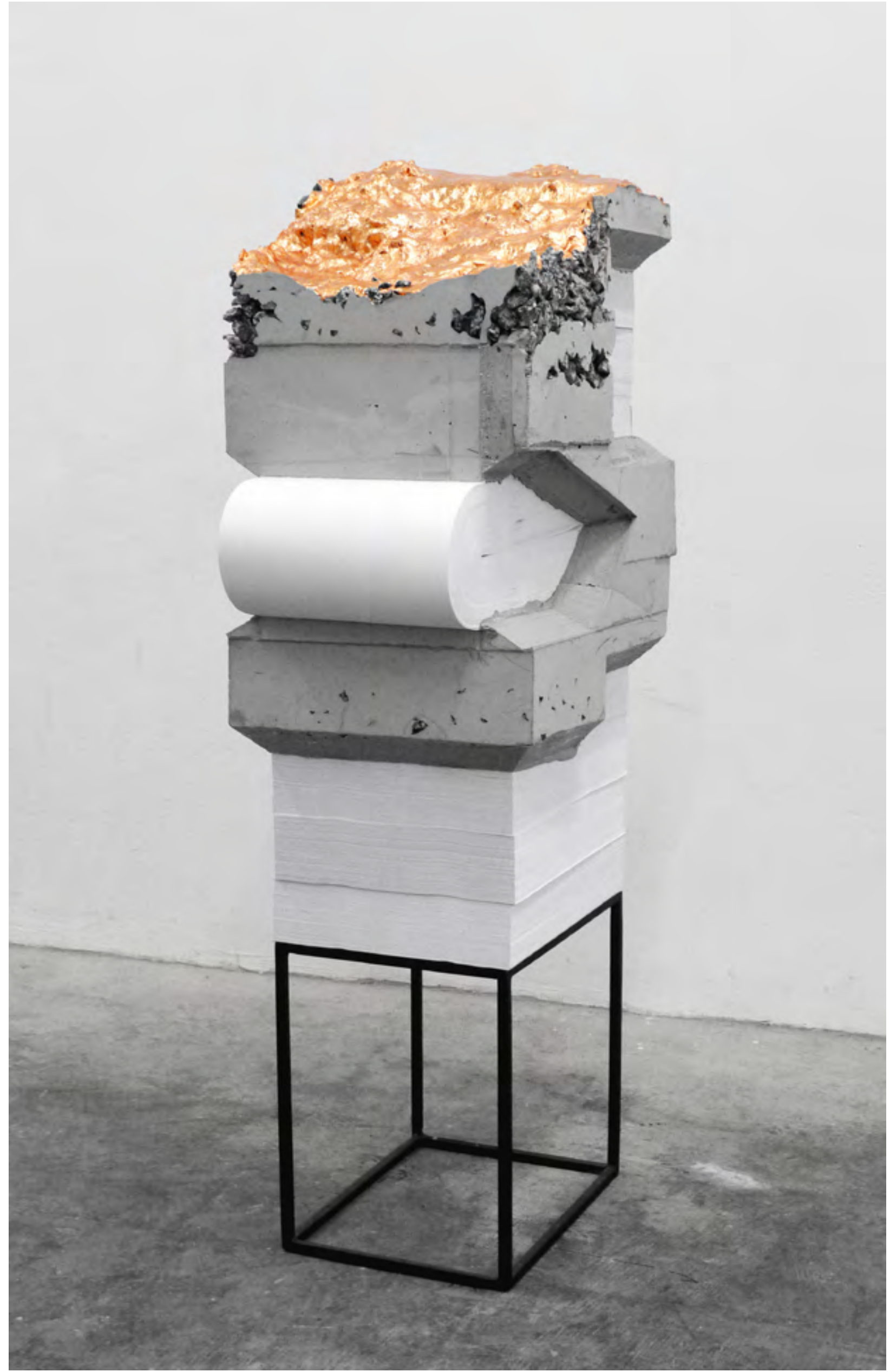




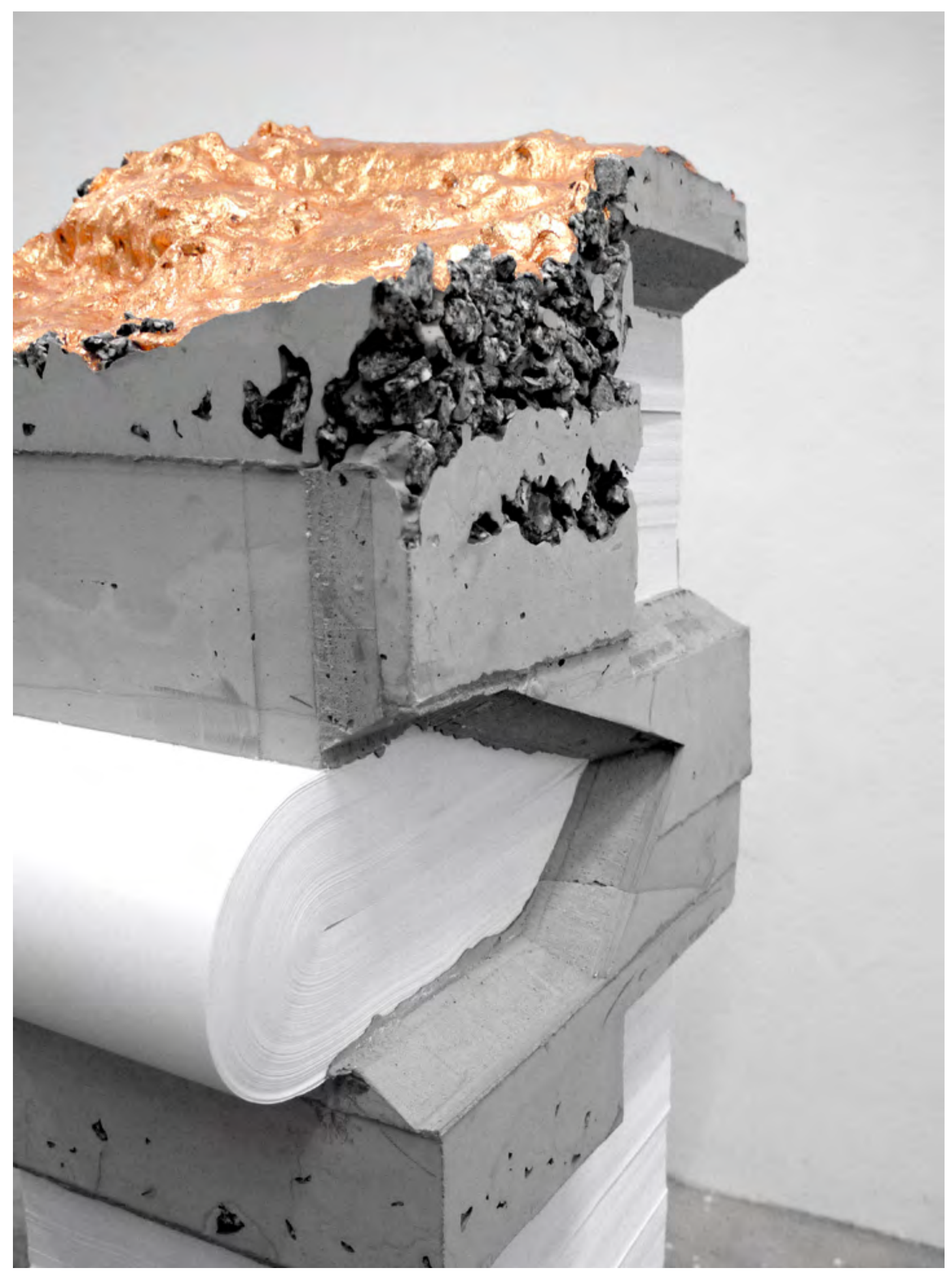

